\title{
1 Do the adaptations of Venice and Miami to Sea Level Rise offer lessons for other
}

2 vulnerable coastal cities?

\section{Emanuela Molinaroli \# Stefano Guerzoni ${ }^{2}$ Daniel Suman $^{3}$}

5 'Dipartimento di Scienze Ambientali, Informatica e Statistica, Università Ca' Foscari, Venezia, 30175 (Italy),

6 e-mail:molinaro@unive.it

$7 \quad{ }^{2}$ International Marine Center, Torregrande, Loc. Sa Mardini - 09170 Oristano (Italy), e-mail:

8 s.guerzoni@fondazioneimc.it

$9{ }^{3}$ Department of Marine Ecosystems and Society, Rosenstiel School of Marine and Atmospheric Science,

10 University of Miami, Miami, Florida (USA), email: dsuman@ rsmas.miami.edu

12 (\#) corresponding author: molinaro@ unive.it

13 ORCID: 0000-0001-6638-0411

15 Conflict of Interest: The authors declare that they have no conflict of interest.

Abstract

18 Both Venice and Miami are high-density coastal cities that are extremely vulnerable to rising sea levels and 19 climate change. Aside from their sea-level location, they are both characterized by large populations, valuable 20 infrastructure and real estate, and economic dependence on tourism, as well as the availability of advanced 21 scientific data and technological expertise. Yet their responses have been quite different. We examine the 22 biophysical environments of the two cities, as well as their socio-economic features, administrative 23 arrangements vulnerabilities and responses to sea level rise and flooding. Our study uses a qualitative approach 24 to illustrate how adaptation policies have emerged in these two coastal cities. Based on this information, we 25 critically compare the different adaptive responses of Venice and Miami and suggest what each city may learn 26 from the other, as well as offer lessons for other vulnerable coastal cities. In the two cases presented here it 27 would seem that adaptation to SLR has not yet led to a reformulation of the problem or a structural 28 transformation of the relevant institutions. Decision-makers must address the complex issue of rising seas with 29 a combination of scientific knowledge, socio-economic expertise and good governance. In this regard, the "hi30 tech" approach of Venice has generated problems of its own (as did the flood control projects in South Florida 31 over half a century ago), while the increasing public mobilization in Miami appears more promising. The 32 importance of continued long-term adaptation measures is essential in both cities.

\section{Acknowledgements}

35 We would like to thank Andrea Barbanti for preliminary discussion on the outline of the paper. The authors wish to thank Gian Marco Scarpa for the support drawing Fig. 1 and Keren Bolter for Fig. 5. We are grateful to the anonymous reviewers who provided helpful comments on our manuscript. This study was financed by IRIDE Program 2016, “DAIS Incentivi alla ricerca individuale”, funded by University Ca' Foscari of Venice. 


\section{Introduction}

41 Climate change is expected to have severe impacts on coastal areas in particular due to sea level rise (SLR).

42 This can increase flood risk, coastal erosion and loss of low-lying systems (e.g., deltas, coastal lagoons, barrier

43 islands) due to permanent inundation (Kirwan and Megonigal 2013; Passeri et al. 2015). The most recent mean

44 global SLR projections by the Intergovernmental Panel on Climate Change (IPCC 2014) range from 0.32-0.63

$45 \mathrm{~m}$ by 2081-2100 for the RCP4.5 and RCP6.0 emissions scenarios. Other IPCC emission scenarios increase the

46 likely envelope to $0.26-0.82 \mathrm{~m}$ (IPCC 2014). Independent estimates of future sea level suggest that global SLR

47 could approach or possibly exceed $1 \mathrm{~m}$ by 2100 (Pfeffer et al. 2008; Vermeer and Rahmstorf 2009; Nicholls

48 2011; Kopp et al. 2016; De Conto and Pollard 2016).

49 The impact of SLR is not felt equally around the globe; some locations experience greater rise than others

50 because of subsidence of local terrain, local hydrological factors, and oceanic currents, among other regional

51 factors such as glacio-isostatic adjustment (GIA) (Thead 2016). Several studies examined the vulnerabilities of

52 global coastal cities to climate hazards (De Sherbinin et al. 2007). Adaptation measures are difficult to

53 implement because they require long time horizons, whereas politicians typically operate on short-term

54 horizons. Incentives need to be intelligently designed so that politicians, officials and the private sector find it

55 in their interests to build less risk-prone cities. Varrani and Nones (2017) compared Jakarta and Venice and

56 suggested a mixed approach of adaptable planning instruments that consider future uncertainties. Moreover,

57 they suggest that policymakers and system designers should use approaches developed to create adaptive plans,

58 which are flexible and can respond when new information appears or when conditions in the environment

59 change. Fu et al. (2016) compared adaptive planning strategies for SLR of US coastal cities. They found that

60 the analyzed localities always lack the necessary information and incentives to plan for emerging issues, such

61 as SLR. The contemporary plans are limited in their planning toolkit, and the existing plans generally led to

62 weak implementation of the adaptation strategies, as well as tenuous establishment of linkages to local planning

63 endeavors. To examine these issues further, we review and critically compare the regions surrounding Venice,

64 Italy and Miami, Florida, USA. Both regions are experiencing recent acceleration of the SLR and have 65 transportation infrastructure, storm and wastewater systems, drinking water supplies, energy grids, real estate, 66 as well as human and ecosystem and populations that are highly vulnerable and at risk. Both have adopted 67 many of the same interventions although the contexts vary. At the same time, we note some significant 68 differences in adaptive strategies due to the physical settings, administrative, political, and social realities.

69 Nevertheless, both cities' adaptation measures may be effective and could have global applicability. We 70 explore the lessons that Venice and Miami can offer each other, as well as to other coastal cities to counter the 71 effects of rising seas.

\section{Study cites}

74 Our work analyzes the physical and socio-economic settings of the two cities, as well as their administrative environments. We examine and compare the management strategies implemented to counteract the effects of the SLR in both cities. 
81 Founded in the $5^{\text {th }}$ Century, Venice became a major medieval maritime power in the Mediterranean. The

82 Venice Lagoon houses over 100 small islands, the largest of which have been urbanized over the centuries (Fig.

83 1a). The Venice Lagoon appears to be one of the most vulnerable zones to SLR in Italy, with several square

84 kilometers of land at or below sea level. In particular, most of the wetlands and beaches of the $\sim 300 \mathrm{~km}$ of

85 North Adriatic coast present medium-to-high vulnerability to inundation and flooding (Lambeck et al. 2011;

86 Torresan et al. 2012).

87 The average water level in Venice Lagoon is $\sim 25 \mathrm{~cm}$ above the 1897 standard (Carbognin et al. 2009; Zaggia

88 et al. 2017). The variability and specific tide guage data were extensively discussed also by Camuffo et al.

89 (2017); land subsidence (human-induced subsidence, eustasy, and morphological changes in the Lagoon) and

90 SLR are jointly responsible for higher water levels that have caused increasingly frequent flooding (Fig. 2). The

91 most dramatic flooding event was the disastrous event of 4 November 1966 when water levels were $1.94 \mathrm{~m}$

92 higher than the 1897 standard (Trincardi et al. 2016). Since then high water events (acqua alta) are even more

93 frequent, and currently around 10\% of the city is flooded 15-20 times a year. In October 2018, the combination

94 of strong winds and exceptionally high tides caused the worst flooding in decades (1.56 $\mathrm{m}$ above the standard).

95 For more than a millenium, Venice has co-existed with the sea and created and adopted numerous interventions

96 to adapt to flooding and the aqueous milieu ${ }^{1}$. Venice is one of the first cities to address rising seas and adapt to

97 this reality. Adaptation measures changed significantly during the past 20 years as the region and Italian State

98 opted for a high tech experimental solution of mobile flood gates at the three entrances to the Venice Lagoon

99 from the Adriatic (MoSE).

100

\section{Miami}

102 Miami was founded merely just over 100 years ago, and today over 2.6 million people reside in the

103 metropolitan area (Miami-Dade County) (Fig. 1b). While Miami lacks the architectural masterpieces of Venice,

104 it also draws millions of tourists and in a sense is a "maritime power" due to its port that labels itself the

105 "Cruise Capital of the World". Also similar to Venice, Miami is extremely vulnerable to flooding and rising

106 seas. Miami is one of 4 major US coastal municipalities out of 180 that exceed the national average for the

107 percentage land area less than $1 \mathrm{~m}$ elevation. About $90 \%$ of Miami is below $6 \mathrm{~m}$ above sea level (Weiss et al. 108 2011).

109 Sea levels in South Florida have increased $20 \mathrm{~cm}$ since the 1930s (Zervas 2009). As global mean sea level 110 continues to climb in the future, extreme events such as storm surges from hurricanes and tropical storms, as 111 well as extreme ("king tides") tides will be superimposed on a higher base level (Sweet et al. 2017) (Fig. 3).

112 Several streets on the west side of the City of Miami Beach flood at least six times per year during "king tides"

113 around the fall equinox. Furthermore, in recent times sea level in Miami area is rising much faster than other

114 places in US (Valle-Levinson et al. 2017) and also faster than the global average rates (Church et al. 2013). The

115 situation is even more complicated, due to uncertain patterns in Atlantic Meridional Overturning Circulation

116 (AMOC), changes in ocean circulation, and changes in gravitational attraction due to ice melt, as well as

${ }^{1}$ In 2011, Venice was chosen as a role model city for cultural heritage protection by the UN Office for Disaster Risk Reduction (UNISDR 2009). As one media commentator noted following the 2012 Super Storm Sandy that caused damages of about $\$ 75$ billion, "The perils of Venice are real; this treasury of civilization does need protecting. But Venice has some lessons to teach about how to live with the sea." 
117 variable rates of SLR due to solid Earth's response to the last deglaciation (Stammer 2008; Milne et al. 2009;

118 Hay et al. 2015). Evaluations of cities most vulnerable to losses from flooding rank Miami in sixth place of 119 global cities and first place of U.S. cities (Ghose 2013). Furthermore, Miami has been recently identified as the 120 economically most vulnerable city to SLR in the world (US National Climate Assessment (Melillo et al. 2014)).

121 Using U.S. Army Corps of Engineers estimates for SLR, the Union of Concerned Scientists predicts that Miami

122 Beach streets will flood about 380 times per year by 2045 (UCS 2016). Zhang et al. (2011) used LIDAR data in

123 a case study of South Florida under $0.5 \mathrm{~m}$ and $1.5 \mathrm{~m} \mathrm{SLR}$ scenarios by 2100 . They suggest that inundation is

124 non-linear and gradual before reaching a threshold when it accelerates due to the region's topography. Miami-

125 Dade County (MDC) is the most vulnerable jurisdiction in their study of South Florida. The smaller SLR value

126 would inundate wetland areas of southeast MDC while the higher SLR value would lead to catastrophic

127 inundation of MDC making it impossible to support today's population on higher ground. Miami has only

128 recently become aware of its vulnerabilities but is actively addressing the threats as we will describe below.

\section{Methodology}

131 This study reviews literature, observations and discussions with government officials, representatives of 132 environmental and civic groups, and natural and social scientists. ${ }^{2}$ Moreover, the authors are researchers in both 133 cities who are closely involved in SLR adaptation issues.

134 The two countries represent distinct cases in relation to the extent of their engagement with planned adaptation.

135 Venice was one of the first European cities to adopt a high-tech adaptation project (Suman et al. 2005) and an 136 associated national and regional implementation plan, complemented by other adaptation actions within various 137 municipalities. To date, Miami has adopted strategies for beach management and flood response (Ariza et al. 138 2014). Within each country, we examine different administrative units to represent areas where interest and 139 action in adaptation were high.

\section{Physical and Human Environments}

\section{Venice}

\section{Physical Setting}

144 The Venice Lagoon forms part of an important barrier - island system; it is the largest shallow coastal lagoon 145 in the Mediterranean region (Molinaroli et al. 2009a). This complex system is affected by multiple natural and 146 anthropogenic forcing factors, and characterized by high heterogeneity in physical, biogeochemical, and 147 biological conditions of mutually interacting habitats (Table 1). A series of man-made changes to Venice 148 Lagoon between the 15th and 20th Centuries (river diversions, construction of jetties at the inlets, and deeper 149 dredging of navigation channels) have had a significant impact on the lagoonal morphology (Molinaroli et al. 150 2009b; Sarretta et al. 2010). By 1968 more than 50\% of the natural lagoon had been reclaimed for business151 related purposes, (e.g., industrial complex of Porto Marghera, fish-farming) (Online Resource 2). All these 152 changes contribute to amplify the flood surge.

153 Venice has literally sunk almost $25 \mathrm{~cm}$ during the last century. For more than 50 years through the 1970s, 154 industries in the area pumped groundwater, a practice that - in conjunction with natural sinking of $10 \mathrm{~cm}$ for

\footnotetext{
${ }^{2}$ The list of people interviewed and documents examined can be found in Online Resource 1.
} 
tectonic reasons - accelerated the city's natural subsidence. Combined with a continuous eustatic rise in sea level, subsidence has further increased relative SLR by $\sim 1.5 \mathrm{~mm} \mathrm{yr}^{-1}$ between 1972 and 2002 and up to $5 \mathrm{~mm}$ $\mathrm{yr}^{-1}$ in the southern lagoon margin in recent years, likely related to the works carried out for the littoral reinforcement (Teatini et al. 2012; Bock et al. 2012; Tosi et al. 2014).

Subsidence of the lagoon has increased the frequency of flooding events (acqua alta) and favored sediment erosion and the increasing influence of marine processes (Fletcher and Spencer 2005; Fagherazzi et al. 2006; Sarretta et al. 2010). In addition to "normal" high water during the last 20 years, ten "exceptional" events (>140 $\mathrm{cm}$ ) have occurred, during which $\sim 80 \%$ of the city surface and more than half of the public space dedicated to pedestrian use have been inundated.

164 Antonioli et al. (2017) projected the relative sea level change along the coastline of the North Adriatic by 2100, as well as flooding risk scenarios for the Venice Lagoon. They utilized three scenarios of expected SLR, of 0.53, $0.97 \mathrm{~m}$ (min and max) and $1.4 \mathrm{~m}$ (Rahmstorf 2012; 2015) and calculated the extent of flooded areas. The lower SLR will flood more than $30 \%$ of the historic city, while the worst scenario will affect more than $85 \%$ (Fig. 4). Moreover, they hypothesized that the combination of SLR and possible decrease of rainfall will produce a negative sedimentary budget and significant shoreline retreat.

170 Estimates of shoreline retreat on the barrier islands of Lido and Pellestrina range from 40-75 m, under SLR scenario of $85 \mathrm{~cm}$ for year 2100 (MAV-CVN 2013). Because barrier islands buffer the mainland coastal areas

172 from storm surge and ocean waves, changes in their shape or partial disappearance due to erosion may lead to a reduced protection of the Lagoon and Venice (Ramieri et al. 2011).

\section{Human Activity}

During the past century the resident population in historic insular Venice decreased from $\sim 170,000$ to $\sim 50,000$ today. Moreover, due to deterioration of the housing stock, the increasing frequency of floods, increasing numbers of inhabitants continue to move from the historic city to mainland urban centers (Favero 2014). As a result, the ancient city has become a residential, tourist, and cultural centre. Approximately $70 \%$ of the sales of residential property in Venice involves international buyers, and consequently, the housing costs in Venice are the highest of any Italian city - almost $\$ 5,000 / \mathrm{m}^{2}$ (Idealista 2015)

182 Tourism is Venice's most important economic activity, but also a major source of pollution, as well as a

183 negative influence on the quality of life of Venetian residents. The "tourist presence" has increased from 1.5 million person-days in the 1950s to about 10 million today, with about 4 million visitors staying an average of

1852.3 days. In addition, some 15-20 million daily visitors, including some 2 million cruise tourists, arrive each year, compared to around 200,000 in 1990.

Other economic activities not directly related to the historic city are chemical industries, the modern commercial port, and beach tourism (Lido and nearby barrier islands). At the end of the 1970s Venice became the main port of the Northern Adriatic Sea. Currently, the average number of port calls is around 3,500 with 3,000 through the Malamocco Inlet (essentially all commercial vessels) and 500 through the Lido Inlet (mostly cruise ships). Legislation prohibits cruise ships over 90,000 tons from entering the lagoon because of the risks they create when passing through the Grand Canal, and institutions were obligated to find an "alternative 
route" $^{3}$. The competent institutions have proposed several alternatives that have been rejected for various reasons (environmental impacts, risks, required dredging).

195 The need for protection of Venice and its lagoon from high-water became evident after an assessment of the damage caused by the dramatic floods of November 4, 1966. That event caused $\sim$ US $\$ 400$ million damage to people, buildings and monuments and also led the Italian Legislature to approve the Special Law setting the stage for broad interventions to minimize the vulnerability from future floods. Vergano et al. (2007) calculated damage estimates ranging between $\$ 10$ and 30 million for each of the 15 exceptional high tide events (over 140 $\mathrm{cm}$ ) that have occurred since 1966. The impacts of climate change on coastal tourism, focusing on the historical center of Venice, for example, have been estimated at a loss of €35-40 million in 2030. Similar estimates have been made for the clam aquaculture, focusing on the most important areas of the Venice Lagoon in terms of productivity (a loss of €10-17 million in 2030). Flooding from SLR in Venice may result in losses in economic activities of perhaps more $€ 100$ million in 2030 (Carraro and Sgobbi 2008).

\section{Three Special Laws for the Protection of Venice}

The First Special Law for the Protection of Venice (Law No. 171, 1973, "Interventions for the Safeguarding of Venice") declared that the Venice Lagoon (VL) area represented important national interests due to its environmental, scenic, historical, archaeological, artistic, and socio-economic features. The legislation created an inter-institutional committee (Comitato) composed of the Minister of Public Works (chair), Minister of Education, Minister of the Economy, Minister of the Merchant Marine, Minister of Health, Minister of Agriculture and Forestry, President of the Veneto Regional Commission, President of Venice Provincial

213 Administration, the Mayors of Venice and Chioggia, as well as representatives of two additional municipalities.

214 The Special Law established the exceptionally broad authorities of the State (National Government) in VL: regulation of water levels in the lagoon and defence against high waters ("Acque Alte"), lagoon boundaries, port infrastructure, littoral defence, restoration of state-owned historic buildings, canal and bridge systems, restoration of publicly owned art, and management of natural and artificial waterbodies that could be important in saving Venice.

219 This first special law also instituted a Commission for Safeguarding Venice (CSV) that would have broad representation, including the President of the Veneto Region (presiding chair), representatives of national ministries (Public Works, Merchant Marine, Agriculture and Forestry), president of the Venice Water Authority (Magistrato alle Acque: MAV), as well as numerous regional, provincial, and municipal officials. The membership of the commission was established at 20 persons. The mission of the CSV focused largely on interventions related to buildings and monuments, as well as land use modifications resulting from public or private works.

226 The second Special law (Law No. 798, 1984, "New Interventions for the Protection of Venice") is specific about national funding. The legislation specified the precise distribution of the national funds among the different governmental levels (State, Region, Municipalities, Port Authority), as well as their destination for specific projects.

\footnotetext{
${ }^{3}$ Ministry of Infrastructure and Transport. Decree of 2 March 2012. General provisions to limit or prohibit the transit of merchant ships for the protection of sensitive areas in the territorial sea. (Official Journal No. 56 of 7-3-2012). Due to a derogation from the law in 2018 the large vessels, with a maximum limit of 90,000 tons, still entered the lagoon.
} 
Funds were to be dedicated to projects, and infrastructure to return the hydrological equilibrium of the lagoon; address the degradation of the watershed; protect against flooding of urban areas - including construction of moveable gates at the lagoon entrances (MoSE); implement antipollution efforts; build coastal defense structures; maintain lagoon boundaries; protect historical buildings; and develop studies to reroute petroleum shipments in the lagoon and open fish farms to tidal flows.

235 This more recent legislation modified the membership of the Comitato. The presiding chair became the President of the Council of Ministers. Revised membership included the Minister of Cultural and Environmental Patrimony, Minister of Ecology, and Minister of Scientific Research. Law No. 798 authorized the Ministry of Public Works to grant contracts for these works and studies to a sole concessionaire. Thereafter, the Ministry of Public Works and the MAV granted this concession to Consorzio Venezia Nuova (CVN). In order to finalise the planned interventions MAV and CVN have signed 8 covenants, for a total budget $€ 800$ million. The same law established that the Comitato's responsibilities included direction, coordination, and control of the execution of interventions programmed and funded by this legislation.

243 The third Special law (Law No. 139, 1992, "Interventions for the Protection of Venice and its Lagoon") distributed funds and responsibilities among the different levels of government. This most recent special law defined the responsibilities of the Region (pollution prevention, cleanup in the watershed immediately adjacent to VL, establishment of environmental standards) and the Venice Municipality (cooperation with the Region

\section{Miami-Dade County (MDC), Biscayne Bay and Barrier Islands}

\section{Physical Setting}

251 Toward the east of mainland Miami lies shallow Biscayne Bay and the barrier islands of Miami Beach, 252 Virginia Key, and Key Biscayne, with elevation ranging between $1.5 \mathrm{~m}$ and $3.5 \mathrm{~m}$ above MLW. Topography was not a reliable diagnostic feature of prior coastal landscapes because the land surface was generally formed

254 by wetlands or sandy plains of low local relief, except for outcrops of the karstified Atlantic Coastal Ridge (ACR) and coastal dune systems. The study area is a nearly level plain with a general elevation of 0-8 $\mathrm{m}$ above sea level except along the ACR, which rises to $\sim 12 \mathrm{~m}$.

257 The coastal configuration of MDC is controlled by the underlying bedrock (e.g., Banks et al., 2007). The 258 bedrock in the region consists of Quaternary Key Largo limestone overlain by oolitic facies of Miami 259 limestone that was exposed to precipitation and air during glaciations leading to partial dissolution (Foster 1983; Finkl and Andrews, 2008; Precht and Miller, 2007). The bedrock controlled the seafloor morphology and shoreline position (Banks et al., 2007; Finkl and Warner 2005). A great number of coastal sediment bodies were built between 3300 and 3000 YBP and also between 2300 to 2500 YBP (Wanless et al. 1994). Land surface morphology in the area is related to (1) materials of the land, (2) oscillations of sea level, (3) shoreline processes, (4) climate, (5) solution of parent rocks, and (6) erosion (Finkl \& Restrepo-Coupe 2007). Finkl and Andrews (2008) showed how depressions in the bedrock provided accommodation space for marine sediments between shore-parallel lithified paleoshorelines, currently buried onshore by recent sediments. The topography of the area was also shaped by the glacio-esustatic fluctuations of sea level during the Quaternary. Higher than present sea levels deposited a layer of marine sands to produce terracing of the landscape. The 
rocky ridge coral reef facies surrounding these inter-reefal flats rise up from the underlying bedrock to form the

271 Florida Reef Tract (FRT), a coral reef system that extends longshore (Precht and Miller, 2007).

272 The previously mentioned barrier islands are parallel to the offshore coral reefs and to the exposures of bedrock on the seafloor. Although some may have been barrier islands, most appear to have been barrier spits connected to the mainland. Today we observe the result of inlet cutting that occurred many decades ago. Therefore, the barrier islands are not true barrier islands, but the result of coastal engineering (Finkl 2014). Commonly barrier islands are composed of sediments that lay unconformably on a substrate, (e.g., Venice Lagoon area). The MDC barrier islands are rock-cored.

278 The limestone bedrock is, very porous and highly permeable and today holds the surficial Biscayne Aquifer. Biscayne Bay occupies a limestone depression east of the mainland extending some $48 \mathrm{~km}$ north to south with widths of up to $13 \mathrm{~km}$. The bay is shallow with natural depth in the center of 2 to $4 \mathrm{~m}$ (Hoffmeister 1982). The central and southern bay has natural shallow openings to the Atlantic unlike the more isolated northern bay. Freshwater delivery to Biscayne Bay occured naturally through some 12 transverse glades, diffuse freshwater flow, and groundwater (Biscayne Aquifer) (Obeysekera et al. 1999; Lodge 2010). Northern Biscayne Bay has been extensively modified during the past century (Online Resource 3). Two inlets have been opened to the Atlantic. Most of the fringing mangroves have been removed, filled, and bulkheaded for residential development. Serious alteration of freshwater delivery to Biscayne Bay began in 1948 with the approval of the Central and Southern Florida Project for Flood Control that resulted in severe alteration of the Everglades ecosystem located to the west of the Atlantic coastal ridge (Grunwald 2007). The project's canals reduced the freshwater sheet flow south to Everglades National Park and Florida Bay (Sklar et al. 2005; Aumen et al. 2015). This major infrastructure project constructed a series of levees and canals that block sheet flow to Biscayne Bay and reduced risk of flooding opening vast areas of the county to residential development. The diffuse flows and trans-glade wetland flows have been changed to point sources with the construction of 19 drainage canals that are opened and closed in manners to avoid flooding and saltwater intrusion into the Biscayne Aquifer. As a result, Biscayne Bay has lost many of its estuarine functions and has become much more saline (Lodge 2010). The barrier islands of Miami Beach, Virginia Key, and Key Biscayne were built up with dredged material from Biscayne Bay (second decade of the 20th Century) (Goodell 2017). Preliminary results from Fiaschi and Wdonski (2016) detected localized subsidence, up to $3 \mathrm{~mm} / \mathrm{yr}$ during the period 1993-2005, mainly in reclaimed land located along the western side of Miami Beach. Although the detected subsidence velocities are quite low, their effect on the flooding hazard is significant, because houses originally built on higher ground have subsided since the city was built, about 80 years ago, by $16-24 \mathrm{~cm}$ down to flooding hazard zones. The combined effect of subsidence, SLR, and increasing groundwater levels further expose subsiding areas and low-lying areas to the west of the coastal ridge to high flooding hazard (Bloetscher and Romah 2015). The South Florida peninsula contains the only subtropical climate in the US mainland (Corcoran and Johnson 2005); the region has high exposure to hurricanes and associated storm surges, as well as high rainfall events. Of the Category 3 to 5 hurricanes that made landfall on the US Atlantic Coast between 1851 and 2008, 39 percent struck Florida (NOAA/AOML 2009). Based on over a century of data, the average return period for a 

years as the frequency at which a hurricane could be expected within 50 nautical miles of Miami gives the 312 annual probability of a strike between $14 \%$ and $20 \%$.

313 Pielke et al. (2008) calculated normalized hurricane damages in the USA from the years 1900 to 2005 and noted that of the top 20 normalized damages from hurricanes, 9 impacted Florida. The Great Miami hurricane of 1926 could produce $\$ 500$ billion in damages were it to occur after 2020. Increased storm intensity (Patricola and Wehner 2018) compounded with Florida's rapid coastal development, population increases, and SLR suggests that potential losses to property from tropical storms will be extremely high. Nicholls et al. (2007) ranked 130 key port cities around the world for the most exposed to coastal flooding assuming SLR of $0.5 \mathrm{~m}$ by 2070. Miami ranked in 1st place in exposed future assets in 2070 and $9^{\text {th }}$ in terms of population exposed to coastal flooding. Fig. 5 illustrates the projected impact of flooding in MDC taking into account both SLR and the storm surge generated by a Category 3 hurricane ${ }^{4}$.

\section{Human Activity}

324 The Miami modern history only began in 1896 with the arrival of the Florida East Coast Railway that brought tourists from the northern US. From a population of 4,955 persons in 1900, MDC's population increased to 488,689 persons by 1950. By 2010, the county's population had surpassed 2.5 million people (Table 1). MDC has more people living less than $1.3 \mathrm{~m}$ above sea level than any state except Louisiana (and Florida itself). About 25 percent of the county's land is less than $1 \mathrm{~m}$ above sea level. The City of Miami Beach, located on the barrier island of its name, is located at elevation of $1.3 \mathrm{~m}$ above MSL. In 1915, Miami Beach housed about $10 \%$ of the county's population until about 1950. The population peaked in 1980 and since that time, has decreased slightly toward the present level of $\sim 88,000$ (Suburban Stats 2018). The smaller barrier island of Key Biscayne to the south of Miami Beach, has a current population of 12,000 persons (Suburban Stats 2018) barely sitting above the sea with average elevation $1 \mathrm{~m}$.

334 The growth of MDC has been explosive during its 120 year history. This fast growth rate has presented challenges for comprehensive land use planning. Despite the region's vulnerabilities, high rates of growth and property values continue to increase. Florida's lack of state income tax means that MDC has a high dependence on local property taxes for its budget. Since 2006, Miami Beach has experienced a SLR of $9 \mathrm{~mm}$ per year (Wdowinski et al. 2016; Treuer et al. 2018). Assuming similar rates in the future and no adaptation measures, a SLR of $0.5 \mathrm{~m}$ by 2070 could threaten assets of $\$ 3.5$ trillion in MDC and displace 300,000 persons (Hanson et al. 2011; Hauer et al. 2016, Treuer et al. 2018). Rao (2016) suggests that a $2 \mathrm{~m}$ SLR could result in lost home values of $\$ 400$ billion in Florida by 2100. An intermediate SLR range predicted by NOAA for 2050 could result in annual flood losses of $\$ 25$ billion (Sweet et al. 2017; Treuer et al. 2018). Assuming population growth, moderate SLR rates, and implemented adaptation measures, losses from flooding in Miami may still increase to $\$ 2.55$ billion by 2050 (Hallengatte et al. 2013; Kulp and Strauss 2017).

345 The principal economic activities in MDC today are tourism, real estate development, financial services, and international trade. MDC accounted for about 30 percent of the $\$ 71.8$ billion that visitors to Florida spend each

\footnotetext{
${ }^{4}$ Using sophisticated modeling to predict SLR impacts, Lentz et al. (2016) illustrate that simple inundation models of SLR may be too simplistic and may not lead to the best prediction of SLR impacts. They suggest that the type of land cover (e.g., beaches or wetlands) may have some capacity to respond dynamically to SLR.
} 
year. Miami Beach attracted over 7 million overnight visitors in 2015 who spent almost $\$ 12$ billion during their

\section{Political-Administrative Environments}

\section{Venice}

352 Several institutions possess administrative and technical competence to deal with problems related to climate 353 change in Venice. Among these are Italian governmental agencies at the State (national), regional, provincial, 354 and municipal levels, as well as UNESCO $^{5}$. Ideally, institutional coordination should support effective management of the Venice Lagoon in light of threats. Constant change presents additional management challenges, a reality examined by both Suman et al. (2005) and Munaretto and Huitema (2012). Suman et al. (2005) studied the Venice Lagoon and its watershed with reference to integrated coastal management. Those authors argued that - at that time - public participation and area-based management were often neglected by administrative bodies involved in the planning of coastal projects and public works. Their analysis highlighted a substantial absence of coordination among the various administrative bodies in charge of planning and management at various governmental levels and various economic sectors. More recently, Munaretto and Huitema (2012) have analyzed water and environmental management in the Venice Lagoon and have concluded that the existence of the Special Law no. 789 of 1984 inhibits participation and real polycentricity, making it difficult to change policy and address problems on a bioregional scale. The complex division of responsibilities and the extensive set of public and semipublic authorities (e.g., the Water Authority, the Veneto Regional Government, the Superintendency for the Architectural and Landscape Heritage of Venice, the Venice Port Authority) involved in the management of the Venice Lagoon suggest that the system indeed exhibits a certain degree of polycentricity in the sense that power is shared among many actors with overlapping responsibilities. The authors suggested "adaptive co-management" as a way to manage challenges of environmental governance, including uncertainty. The recent changes of some of the administrative bodies and the appearance of a new administrative entity - the Metropolitan City - create additional complexity. We note the principal actors below, and their relationships in Fig. $6{ }^{6}$

“"Interregional Superintendency for Public Works for Veneto, Trentino Alto Adige and Friuli Venezia Giulia", previously Venice Water Authority (VWA), a branch of the national Ministry of Infrastructure and Transport, is responsible for pollution abatement and maintenance in the lagoon, as well as flood defenses. Eastern Alpine Basin Authority, is responsible for management plans of all regional water bodies .

The Veneto Regional Government is responsible for pollution abatement in the lagoon's drainage basin, tourism and transport on the mainland, landscape, and some aspects of navigation.

379 The recently created Metropolitan City of Venice will take over some of the responsibilities of the communes 380 around the lagoon and the Province. ${ }^{7}$ The Venice Port Authority, a national entity, is responsible for shipping channels across the lagoon, the Giudecca Canal through Venice, and the ports in Venice and around the lagoon.

\footnotetext{
${ }^{5}$ Venice and its lagoon were added to the list of UNESCO World Heritage Sites in 1987.

${ }^{6}$ A complete list of the institutions involved and their respective roles is available in Online Resource 4.

${ }^{7}$ The Province in 2008 prepared a Flood Plan ("Piano Mareggiate") with a management geodatabase of the Venetian coasts containing all geomorphological data.
} 
382 Roggero and Fritsch (2010) explored the governance arrangement concerning fishery management and 383 morphological remediation of Venice Lagoon and underlined some negative aspects directly linked to the scale 384 of the agencies involved.

385 Rusconi (2016) analyzed the problems related to lagoon management after the 2014 elimination of the Venice 386 Water Authority (VWA), arguing that it was inappropriate to define the tasks of the eliminated VWA only 387 related to the Venice Lagoon, neglecting the overall hydraulic and maritime contexts. Ecosystem-based 388 management of the waters of the "Hydrographic Sub-unit of the Watershed, Venice Lagoon and Adjacent Sea" 389 is required, according to the Management Plans implemented by the Veneto Region. The absence of a 390 coordinating body, potential conflicts between a new Special Law now under discussion and European 391 Directives (Water and Floods), and the potential transfer of overall management to the Metropolitan City of 392 Venice are issues that create uncertainty.

393 A management plan was finally created in 2012 for the Venice UNESCO World Heritage Site. However, this 394 document only gives superficial discussion of SLR. In 2015, UNESCO warned that Venice might be included 395 in the list of UNESCO "World Heritage Sites In Danger" if Italy had not banned large cruise ships from the city's lagoon and created a sustainable tourism strategy (UNESCO 2015).

\section{Miami}

399 Miami's administrative framework is less complex than that of Venice and is divided between the national 400 (federal) government, the State of Florida, MDC and its municipalities. While perhaps less complex, the US 401 situation remains challenging and vertically fragmented. Fig. 7 shows the relationship between the institutions. ${ }^{8}$ 402 The federal government appeared to be moving toward action to address climate change during the Obama 403 Administration. In February 2013, Federal agencies released their first Climate Change Adaptation Plans. The 4042013 President's Climate Action Plan summarized federal agency policies to address climate change issues. 405 Key among the identified efforts was the development of partnerships between federal agencies and local 406 governments to assess vulnerability to infrastructure and identify solutions that reduce risks. Federal efforts 407 would support community-based efforts to prepare for climate change and enhance resilience via federal grants 408 and technical assistance. However, the Trump administration from January 2017, has retreated from numerous 409 climate change initiatives. Nevertheless, the U.S. Global Change Research Program's Fourth National Climate 410 Assessment clearly states the urgent need for enhanced, coordinated adaptation efforts (Fleming et al. 2018; 411 Maxwell et al. 2018). Despite these policy shifts from the Executive Branch, numerous federal agency 412 programs continue to have direct relevance to SLR and flooding. Of particular significance are the programs of 413 the US Army Corps of Engineers (USACE) and the Federal Emergency Management Agency's National Flood 414 Insurance Program. The USACE is responsable for developing infrastructure that protects against flooding. The 415 USACE, together with the South Florida Water Management District, are the principal actors of the 416 Comprehensive Everglades Restoration Plan (CERP) at a cost of over US\$10 billion with a timeline of over 3 417 decades (Aumen et al. 2015). We address CERP's linkages to SLR adaptation in eastern MDC below.

418 Major federal agency efforts examining various aspects of climate change and sea level rise provide important 419 information for local adaptation efforts. The US Geological Service (USGS) has collaborated with MDC in the 420 generation of 30 year scenarios of SLR and increased groundwater pumping that indicate elevation of the water

\footnotetext{
${ }^{8}$ A complete list of the institutions involved and their respective roles is available in Online Resource 4.
} 
421 table contributing to increased vulnerability from flooding (Hughes and White 2016). The National Oceanic and Atmospheric Administration's Coastal Services Center has developed numerous tools that provide coastal managers with information for their adaptation efforts. Among these are coastal LIDAR data, an online mapping viewer to illustrate potential SLR and flooding in coastal areas, and integrated shoreline data from NOAA and other federal agencies available on a single website (https://shoreline.noaa.gov/about.html).

426 Despite Florida's high vulnerability to climate change impacts, in recent years at the State level, planning for response and adaptation to climate change not been directly addressed because of the political leadership remained in the hands of climate change skeptics (Korten 2015). In a 2012 evaluation of states' preparation planning for climate change, the Natural Resources Defense Council (NRDC) ranked Florida in Category three out of four categories; the 29 states in Categories three and four are "largely unprepared and lagging behind" (NRDC, 2012). Nevertheless, Florida's Land Use Planning legislation obligates counties to develop proactive comprehensive land use plans (F.S. Chapter 163) and provides counties with the opportunity to create "Adaptive Action Areas" (AAA) that experience coastal flooding due to extreme tides, storm surges, or vulnerability to SLR. AAA designation is a key to priority funding for adaptation planning (Bloetscher et al. 2016).

436 At the regional government level, the Southeast Florida Regional Planning Council (SEFRPC) is a four county (Palm Beach, Broward, Miami-Dade, Monroe) planning agency that recommends regional plans and advises counties on specific development projects. As we describe below, the SEFRPC is playing a leading role in coordinated SLR adaptation. The South Florida Water Management District, one of five in Florida, has begun to consider climate change and SLR in water resources planning in the Everglades ecosystem and Southeast Florida (SFWMD 2018).

442 The local government is led by strong MDC Mayor and Board of County Commissioners with authority over schools, water and sewage, and land use planning. Governance is shared between the MDC government and some 34 muncipalities, as well as incorporated areas. Municipalities are responsible for zoning, code enforcement, police, and fire protection. MDC's Office of Resilience assesses vulnerabilities and forges collaborations with county agencies, other levels of government, and stakeholders to promote environmental sustainability. The Office of Resilience has coordinated the development in 2014 of the County's first Climate Action Plan that addresses mitigation measures to reduce greenhouse gas emissions and measures to adapt to climate change impacts (Miami-Dade County 2014a). As we will mention below, some of the County's

\section{Adaptation Efforts}

453 Adaptation to climate change is essential to manage present risks and potential for more serious future changes, 454 and has entered the planning agenda of many cities around the world (Araos et al. 2016; Juhola and Westerhoff 2011). With improvements in high-resolution modeling, it is possible to map the expected SLR in specific 456 locations (LIDAR), both worst-case and expected-case scenarios. In many locations this very detailed awareness of vulnerability leads to proactive planning actions (De Sherbinin et al. 2007). Venice and Miami are both struggling to maintain their environments and economic activities faced with high vulnerability to flooding caused by climate change (Hauer et al. 2016; Antonioli et al. 2017). This section describes some 
462 Venice has a long history of adaptation to flooding. Early Venetians developed technologies to build on the

463 water, construct firm foundations, and raise building heights (Mancuso 2014). Archaeologists have found signs

464 that ancient Venetians gradually raised the ground level as high as $\sim 2 \mathrm{~m}$. In St. Mark's Square, the lowest point 465 of Venice, there are five levels of older pavement beneath today's plaza (Keahey 2002). The inhabitants of 466 Venice diverted the lower course of the rivers to shape the city to their needs (Caniato 2005). In 16th and 17th 467 Centuries city planners actively altered the lagoon and surrounding environments, building canals to help 468 facilitate shipping and further river diversions, as well as constructing sea barriers. During the 18th Century, 469 work continued to improve navigability, and at the barrier island of Pellestrina, the "murazzi" (walls made of 470 cemented rocks) were constructed to form barriers against the sea.

471 More recently, several adaptation measures were adopted in Venice to counteract the flooding events, 472 especially after the "big flood" of 1966. They can be subdivided in widespread interventions and the mega473 technical barrier system, first proposed in 1981 and funded through the 1984 Special Law. The following 474 interventions stem from this legislation: 1) restoration of the seriously damaged murazzi (seawalls) beginning 475 in 1990, 2) nourishment of eroded beaches, 3) prohibition of methane extraction and drilling of new artesian 476 wells, 4) elevation of low-lying parts of the urban center, 5) construction of lagoonal wetlands, and 6) dredging 477 of internal Venice canals.

478 The city is constantly confronted with the problem of acqua alta. To allow pedestrian mobility around the city 479 at high tide, a network of walkways is installed along the main pedestrian routes, generally at $\sim 110 \mathrm{~cm}$ above 480 the standard sea level. Today flood information is provided by alarms and in real time via web and smartphone, 481 and some public transport lines are diverted to alternative routes. Among the non-structural measures for 482 prevention, preparedness and response, Venice also counts on the strong awareness of its citizens and their 483 ability to adopt adaptation measures to protect their assets. Examples of these types of measures are the 484 protection and improvement of ground floors, adaptation of electrical systems, and placement of steel barriers 485 at the entrance to buildings to keep water out (Indirli 2014).

486 Recently, some authors (Gambolati et al. 2009) have proposed a programme of anthropogenic uplift of the city 487 of Venice that would involve the injection of seawater into a 600-800 m deep brackish aquifer underlying the 488 Venice Lagoon (Comerlati et al. 2003, 2004). According to Comerlati et al. (2003, 2004), Venice might be very uniformly raised by $25 \mathrm{~cm}$ over a 10 -year period based on injection boreholes and at controlled injection rates.

\section{MoSE}

492 The centerpiece of the Special Law was MoSE (an acronym for Modulo Sperimentale Elettromeccanico or 493 Experimental Electromechanical Module), begun in 2003 and expected to be completed no sooner than 2020494 2022. The mobile tidal barrier project will prevent flooding through the installation of 78 mobile gates, laid at 495 the bottom of the seabed at the three inlets - Lido, Malamocco, and Chioggia - separating the Venice Lagoon 496 from the Adriatic Sea. ${ }^{9}$ Since 2003 the majority of funding has been dedicated to completion of the MoSE

\footnotetext{
${ }^{9}$ For the constructive details of the MoSE, the debate, the costs and the critical points refer to the Online Resource 5.
} 
project. ${ }^{10}$ As a result, measures that previously had been implemented, such as wetland creation and beach nourishment, ceased for lack of funding.

499 Strong debate has surrounded MoSE since its conception regarding: (1) its effectiveness and high cost

500 (Ammerman and McClennen 2000; Kaluarachchi 2014); (2) changes in the structure of the lagoon inlets, with 501 consequences for the dynamics of the lagoon ecosystem as a whole; (3) the direct costs of the interruption of 502 ship traffic due to the operation of the MoSE, resulting from longer waiting times for ships crossing the Venice 503 Lagoon (Vergano et al. 2010). Further critiques concerned interference with the ship traffic with a sea-level rise 504 of $50 \mathrm{~cm}$ (Umgiesser and Maticchio 2006), as well as environmental degradation, particularly water quality.

505 Finally it was suggested that a potential seismogenic source located inland near Venice might generate a 506

\section{Miami}

509 In Miami initiatives to respond and adapt to climate change and SLR originate primarily at the local level and 510 are relatively recent. The County Commissions of the four southeastern counties (Broward, Miami-Dade, 511 Monroe, and Palm Beach) approved the Southeast Florida Regional Climate Change Compact (SEFRCCC) in 5122010 to create a united front to face regional climate change. Since then, the SEFRCCC Steering Group has 513 adopted consistent methodologies and assessed the vulnerabilities from sea level rise in the four county region 514 based on one, two, and three foot $(0.3,0.61$, and 0.91 meter) increases in sea level. In October 2012, the 515 SEFRCCC produced a Regional Climate Action Plan with 110 Action Items related to reduction of greenhouse 516 gas emissions, water supply systems, sustainable communities, transportation infrastructure, and emergency 517 management that decision-makers at the county and municipal levels can adopt to mitigate and adapt to climate 518 change (Southeast Florida Regional Climate Change Compact Counties, 2012). Although it will take many 519 years to adopt and implement the recommendations, these are important initial planning steps.

520 In 2013, MDC formed the Sea Level Rise Task Force charged with providing recommendations to the 521 County's Comprehensive Development Master Plan (CDMP). The principal Task Force recommendation in 5222014 was to "accelerate the adaptation planning process by seeking and formally selecting the engineering and 523 other relevant expertise needed" to develop plans for flood protection, salinity barriers, pumps, and road/bridge 524 designs (Miami-Dade County 2014b). Many of these adaptive strategies are those suggested by Nicholls (2011). 525 Miami-Dade County CDMP for 2020-2030, issued in 2017, contains 12 elements, several of which directly 526 address climate change and sea level rise (Miami-Dade County 2017). The two most relevant elements are 527 Land Use and Coastal Management.

528 The details of the recent Comprehesive plans (like RCAP and CDMP) are described in Tables 3, 529 "Recommendations and Future". All these goals are important first steps, but they remain to be fully 530 implemented.

531 While MDC has only recently begun to expressly consider the risks of SLR, the region has extensive 532 experience in measures associated with coastal erosion and shoreline protection (Table 3, "Realized"). The 5331926 Category 3 hurricane that struck Miami caused major damage to infrastructure and significant beach 534 erosion on Miami Beach. The first efforts to address coastal erosion began shortly afterward with construction

\footnotetext{
${ }^{10}$ In the period 1992-2004 the average annual funding of the Special Law dedicated to Venice was $€ 143$ million, reduced to $\sim € 20$ million in the period 2005-2014.
} 
535 of wood and rock groins. By the 1950s, no dry sand beach existed on 56\% of the shoreline at high tide. In 1966

536 Congress authorized the MDC Beach Erosion Control and Hurricane Surge Protection Program via the Flood

537 Control Act with the primary goal of addressing beach erosion. Development and implementation of this major

538 beach nourishment program was a cooperative arrangement between the US Army Corps of Engineers

539 (USACE) and MDC. The original project, carried out between 1975 and 1982, excavated $\sim 10$ million $\mathrm{m}^{3}$ of

540 sand, and by $2006 \sim 14$ million $\mathrm{m}^{3}$ of sand had been excavated for beach nourishment. The Miami Beach

541 project is thought to be one of the most successful replenishment projects on the US Atlantic and Gulf of

542 Mexico coasts (Pilkey and Dixon 1996).

543 Additionally, in response to 1992 Hurricane Andrew that caused major damage in MDC, in 2000 the State of

544 Florida Building Commission adopted the Florida Building Code (FBC) and considers amendments every three

545 years. The FBC incorporated stricter building standards for construction, modification, and repair of buildings.

546 Barrier island Miami Beach is the MDC municipality that has been most aggressive in addressing flooding

547 from SLR. In 2014 the municipality began to implement the MDC recommendation to address SLR with the

548 development of design standards for city infrastructure that would account for SLR during a 30 to 50 year time

549 horizon. Based on these standards, design standards for road elevations, stormwater outlets, seawall elevations,

550 and building finished floor elevations were modified. In April 2016 the City of Miami Beach adopted new

551 standards for major renovation and new construction that will provide for increased protection against storm

552 surges and sea level rise. The minimum base flood elevation (BFE) was increased from 7.0 feet NGVD to 8.0

553 feet (2.13 to 2.44 meters) NGVD. Similarly, the Freeboard was increased from 0 feet above BFE to +1 foot to

$554+3$ feet (+0.305 to +0.914 meters) above BFE. Required elevations for seawalls were also increased from 4.76

555 feet (1.45 meter) NGVD to 7.26 feet (2.21 meters) NGVD for seawalls. The ordinance also established a

556 minimum yard elevation of 6.56 feet (2.0 meters) NGVD where none existed previously.

557 Miami Beach has begun to elevate streets in areas that are most vulnerable to flooding. The City initiated the

558 overhaul of its stormwater system with the installation of 70 one-way pumps in areas most susceptible to

559 flooding. These pumps replace the reverse gravity pumps that recently caused street flooding during king tide

560 events. During recent flooding events, the pumps have worked, although they have been responsible for water

561 pollution (fecal matter) of Biscayne Bay.

562 One of the largest hydrological restoration programs in the USA (CERP) is attempting to return the sheet flow

563 of freshwater southward to a more "natural" state before engineering projects shunted much of the freshwater

564 away from southeast and southwest coastal areas that became prime sites for urban development. The original

565 CERP plans did not consider climate change or SLR, but this has begun to change in recent years with new

566 modelling and calls for integrating potential climate change uncertainties (precipitation, upstream flows, SLR,

567 population growth) into long-term ecosystem restoration planning (Koch et al. 2015; Nungesser et al. 2015;

568 Obeysekera et al. 2015). The linkages between CERP and SLR adaptation of coastal MDC have yet to be fully

569 envisioned.

570

\section{Discussion}

572 Having presented the two case studies, we now address the main questions. Tables 2 and 3 summarize the

573 adaptation measures with the pros and cons in each city to allow clear statements on what they could learn from

574 each other. 
575 Initially, we note the commonalities between the two scenarios. Both Venice and Miami are high-density 576 coastal cities that are highly vulnerable to SLR and flooding. Both sites include barrier islands and shallow 577 lagoons that have experienced great anthropogenic modification - increasing their vulnerabilities. Large 578 numbers of tourists visit both cities often by cruise ship, and in fact, tourism is their principal economic 579 generator.

580 Because both cities are highly vulnerable to flooding, we examine the experiences they have with flooding and 581 how management activities have evolved. Flooding and SLR are priority issues in Venice and Miami 582 although the directions the cities have chosen for adaptation differ somewhat. In the historic Venice Acqua Alta 583 flooding has become much more serious and frequent in recent decades - due to regional subsidence, as well as 584 SLR. A certain variability characterizes the natural subsidence ( $1 \mathrm{~mm} / \mathrm{yr})$, mainly because of the 585 heterogeneous nature and age of the lagoon subsoil, consistently with the "geological" subsidence of the 586 "Venice area" of $1.3 \mathrm{~mm} / \mathrm{yr}$ and $0.6 \mathrm{~mm} / \mathrm{yr}$ (Antonioli et al. 2017). Venice is still experiencing land 587 subsidence due to human activities, mainly restoration works. However this component affects the city at a 588 very local scale for short time intervals with rates up to $10 \mathrm{~mm} / \mathrm{yr}$ (Tosi et al. 2013).

589 The adaptation responses have emanated from all levels of government (Table 2). The municipality developed 590 warning plans and designated elevated walkways for residents and tourists. Interventions have also included 591 pumps, abandonment of the ground floors of some buildings, wetland creation and restoration, beach 592 nourishment, seawalls, and, most recently, the adoption of a high-tech experimental solution of mobile sea 593 barriers (MoSE) at the three inlets. Most of these interventions can be adapted to the situation in Miami (Table 594 3). In terms of lessons learned, however, the MoSE project, designed almost four decades ago over which 595 measurable SLR has occurred, has failed to integrate new information about SLR into its evaluation of impacts.

596 As a result, projections suggest that the gates may be closed more often than not. Essentially, with future SLR, 597 the MoSE will become an extremely costly and unacceptable intervention.

598 In Miami awareness and concern about SLR is recent but growing rapidly. Initial efforts to address the threats 599 have begun at the county and city levels with little direct political and financial support from the national and 600 state levels (with the exception of beach renourishment projects). However, actual implementation of adaptive 601 measures is minimal to date. South Florida opted for a high-tech engineering solution to flooding over half a 602 century ago with the Central and Southern Florida Project for Flood Control and is now attempting to remedy 603 the resultant environmental damage with the Greater Everglades Ecosystem Restoration Plan (CERP). This 604 flood control infrastructure project reduced the potential of the ecosystem to respond to climate change. 605 Moreover, the comprehensive package of restoration projects initially failed to consider climate change and 606 SLR. This situation has now begun to change, but the linkages between adaptive management of Everglades 607 restoration and resilience of coastal MDC to SLR have yet to be fully developed.

608 Adaptation strategies have involved numerous governmental levels in both cases. Initial activity in Miami 609 largely involves planning goals with little actual implementation - although the relatively wealthy and 610 progressive City of Miami Beach has begun to elevate some streets, install pumps, and approve new 611 construction regulations. Recent experiences with devastating hurricanes (Andrew 1992 and Irma 2017), as 612 well as king tide flooding events that have drawn much media attention, appear to have begun to create 613 sensitivity in the region to scenarios of impacts from SLR in the coming decades (Wachinger et al. 2013; 614 Treuer et al. 2018). Numerous town hall meetings, citizen workshops, and media events have elevated the 
615 discussion of the issue. This increasing awareness may help to overcome short-term vision and "wait-and-see" 616 attitudes. Nevertheless, Miami's adaptation responses to date illustrate the "low-regrets incremental approach" 617 described by Butler et al. (2016). Local governments are hesitant to overadapt given the uncertainties of SLR 618 magnitude, timeframe, location of impact, and potential success of adaptation measures. ${ }^{11}$ However, as 619 communities, such as Miami Beach, begin to experience impacts of SLR, they become more concerned about 620 not adapting and begin to adopt legally enforceable policies. This could offer an important lesson for Venice, 621 which lacks a public outreach process to facilitate the growth of awareness.

622 Apparently, the "techno" approach of Venice suggests some negativities, while the increasing public 623 mobilization in Miami is noteworthy. Our analysis of the two cities points out that there are other interventions 624 that are worth evaluating. Therefore, more questions arise: What has worked well at each location and do the 625 current long-term management strategies incorporate adaptation?

626 For the historical Venetian city the interventions achieved both in Venice (e.g., elevation of the urban center, 627 alarms in real time, etc.) and along the barrier islands, such as nourishment and restoration of seawalls have 628 worked well. Concerning adaptation to flooding and SLR, all the debates today are related to MoSE and the 629 discussion is absent about the future of the barrier islands (Lido and Pellestrina) and the economic and 630 environmental vulnerabilities that Venice may face by 2050 or 2100 in light of a 50-100 cm rise in sea level. In 631 short, Venice has overrelied on the large experimental infrastructure alternative and has failed to incorporate 632 adaptive management. To effectively implement adaptive management it must overcome its institutional 633 fragmentation constraints. In this light, Venice's experience today is somewhat similar to Miami's seven 634 decades ago with the construction of the Central and Southern Florida Project for Flood Control and the initial 635 Everglades Restoration Project from two decades ago.

636 The Miami Beach nourishment project, initiated in 1975 has certainly been a successful measure, 637 demonstrating the importance of continuing long-term intervention, which has not occurred in Venice. 638 However, the geological setting of Miami and vulnerability to hurricane storm surges makes the adoption of 639 mobile sea barriers similar to those in Venice impractical (Table 2).

640 Both cities illustrate that adaptative management strategies to SLR present scientific/engineering issues, as well 641 as significant ecological and socio-political challenges. Adaptive approaches must integrate the best available 642 technologies along with current information about the environmental health of the ecosystem, residents and 643 communities, and political realities.

644 Venice demonstrates that, while new defense technologies have the potential to reduce vulnerability and 645 diversify management tools, technical solutions in themselves are not necessarily the sole panacea. Rather, it is 646 necessary to integrate the best technical measures into a strategic context that also considers the environmental, 647 social and economic issues specific to any coastal area (Zanuttigh, 2011). The lagoon is a continuously 648 evolving system that responds rapidly to human activities. As such, the long-term health and viability of this 649 important system is contingent upon sound and effective coastal area management that should be an outcome 650 of an integrated vision and participatory and adaptive approach (Suman et al. 2005). Given the complex nature

\footnotetext{
${ }^{11}$ Some debate whether South Florida is rising, falling, or essentially stable, or additionally, whether SLR rates in South Florida differ from current or predicted rates of global SLR. Communities in Florida can more or less use the global/eustatic SLR estimates for their local planning purposes. Florida may be sinking at a rate of about $-0.5 \pm 1.6 \mathrm{~mm} / \mathrm{yr}$. This very preliminary value of $-0.5 \mathrm{~mm} / \mathrm{yr}$ with its very large uncertainty of $\pm 1.6 \mathrm{~mm} / \mathrm{yr}$, should be viewed very cautiously, but a sinking Florida is in general agreement with geophysical models of Earth's changing shape due to post-glacial rebound from the last ice age (Maul 2008).
} 
of how ecosystems function, great care is required in planning any intervention. While the MoSE infrastructure should protect the city infrastructure, serious questions arise whether it will benefit the lagoon ecosystem, the morphological evolution of coast, and the broad suite of Venice Lagoon uses and resources. We question whether Venice and its lagoon will be more resilient to exceptional high tides after the MoSE barriers are completed in 2020-2022. The analogy to Miami is whether the region's flood control projects have been

656 beneficial to Biscayne Bay resources and whether they have created a Biscayne Bay and southeast Florida that are more resilient to SLR.

658 Miami's situation today creates an excellent opportunity for innovation - not only regarding adaptation 659 strategies and also the possibility of linking Everglades restoration projects to SLR adaptation - but also in 660 communication and outreach strategies by government officials, academia, NGOs, and the media. Conversation 661 is focusing on new technologies that might be implemented allowing Miami to continue to exist despite SLR. 662 These concepts include parks as water storage areas, floating homes, and increasing dependence on water 663 transport. Some attention is beginning to identify critical infrastructure and historical structures that must be 664 protected, as well as less "important" and more vulnerable areas that may have to be abandoned. Perhaps 665 Miami may be able to turn the challenges it faces into opportunities and be able to develop expertise in 666 adaptation techniques that could be used elsewhere. The decision-making process appears to be transparent and 667 open to all interested and affected parties. This multiple approach is a good example that could be transferred to 668 Venice, as well as to other coastal cities. Miami needs to learn from Venice's diverse efforts (high-tech, 669 shoreline protection, ecosystem restoration, urban adaptations) - while Venice needs to recognize that lack of 670 coordination can produce numerous problems, such as excessively complicating the decision-making process 671 instead of simplifying it.

672 A crucial question is funding for the adaptive measures. Adaptation in both cities has been costly and will be even more expensive in the future. Although some question the usefulness of the MoSE, for which $€ 4.5$ billion have already been invested, most people believe that the project should not be abandoned. In addition, the estimates for the maintenance and management of the system are around $€ 100-150$ million/yr. In Miami recent models estimate the costs of adaptation (shoreline armoring, beach renourishment, abandoned properties, elevation of land and structures) through 2100 to SLR and additionally SLR combined with storm surge, but similar estimates for Venice and barrier islands Lido and Pellestrina are absent. Adaptation costs in Miami rank the highest of any US city - \$51 billion to adapt to SLR and \$130 billion to adapt to SLR and storm surge (Neumann et al. 2015). Recent research by Treuer et al. (2018) indicates that Miami residents may be willing to pay higher taxes to fund adaptation measures. For example, in November 2017 City of Miami voters approved a general obligation bond of $\$ 400$ million, half of which will pay for SLR mitigation and flood prevention projects, such as pumping stations and stormwater system upgrades (Magill 2017; Smiley 2017). However, in Miami the absence of direct support for adaptive measures at the national and state levels is noteworthy and a serious limitation. Meanwhile, in Venice the funding issue has been addressed at the highest government level with a series of Special Laws that provided significant funding for major infrastructure projects intended to safeguard the historic region. For the future it is likely that this procedure will continue. The national government continued to provide high levels of funding for the most recent measures being implemented in Venice. 
Ideally, financial support should emanate from all levels of government in a coordinated fashion. Treuer et al. (2018) raise a potential funding challenge; if wealthy coastal residents abandon their homes and coastal real estate values plummet, shrinking local revenues may not be capable of funding adaptive measures. Banks may cease approving mortgages for homes or insurers may refuse to issue policies (Flavelle 2017). Nevertheless, coastal housing values in Miami and Venice are high and appear to be increasing. ${ }^{12}$

\section{Conclusions}

697 Although we recognize that adaptation techniques and planning processes are very site-specific (Thead 2016), we conclude that both cities offer valuable lessons that maybe useful in other locations.. We have examined and compared the management strategies implemented in both cities to counteract the effects of the SLR and noted adaptive responses utilized in Venice and Miami that might have applicability elsewhere, as well as their limitations and challenges (Table 2 and 3, "Transferability"). For more than a millenium, Venice has co-existed with the sea and created and adopted numerous interventions to confront flooding and the aqueous milieu, as a result of an alliance between humans and the sea. Those interventions, such as seawall construction, beach nourishment, canal dredging and wetland creation, have been already implemented in both sites. After the 1966 flood Venice began to diversify its adaptive responses, mainly by adopting adaptation measures to protect its assets, i.e., elevation of low lying parts, raising sea walls, upgrading water drainage system, and dune construction and elevation.. Most of these interventions are completely transferable to Miami and other cities. Currently the over-reliance of Venice on the high-tech experimental mobile barriers (MoSE) above other approaches raises many questions. Imposition of a single solution may consume the majority of financial resources. This intervention is not suitable for Miami due to its different geological setting. Although from an engineering perspective the mobile gates may ultimately be successful in Venice, with rising sea levels the adverse impacts on the lagoonal ecosystem and many stakeholders may be profound.

South Florida adopted a high-tech solution to its "threat" of flooding over seven decades ago with its flood control projects. Although successful at flood control, the resulting environmental damage has been profound. Since the turn of the century Everglades restoration projects have begun to address the ecosystem damage but without consideration of climate change. In a sense, the Miami "high-tech" case is "reverse Venice". Recent discussion of adaptation of some restoration projects (construction of forward pumps on existing coastal salinity control structure to better regulate groundwater levels and control saltwater intrusion; increased freshwater flows to coastal wetlands) may assist urbanized MDC adapt to SLR. In Miami today concern about the risk that SLR presents, in combination with hurricanes and resulting storm surges, has greatly increased. Yet, to date, the region has relied primarily on dune/beach restoration as a protective measure. The severe degradation of central and northern Biscayne Bay ecosystems, as well as the porous limestone geological substrate, both constrain adaptive measures that Miami may adopt. The MDC area can learn from Venice and develop information systems to inform the general public regularly on extreme weather events and the threat of

\footnotetext{
${ }^{12}$ Both Venice and Miami potentially may lead to "environmental justice" or "climate justice" scenarios. In Miami, wealthier residents residing in vulnerable coastal properties may displace poorer residents living today on higher ground. Venice has already begun to experience a dramatic exodus of local residents to the less vulnerable mainland as living costs and real estate values soar in the historic city. These are topics that are ripe for future social science research.
} 
flooding. In Venice, several redundant systems operate, such as mobile-phone messages alerts, newspaper advertisements, sirens, and maps with safe exit routes.

729 It appears that in the two cases presented here adaptation to SLR has yet to lead to structural transformation of the governance institutions that would allow the systems to progress towards more effective outcomes. In particular, planned adaptation in both cities remains limited by the lack of ecosystem-based approaches, the lack of horizontal (sectoral) and vertical (inter-governmental) integration, and severe funding constraints. Technical, financial, legal, and political support for adaptation must emanate from all levels of government in a coordinated fashion for change to occur. Miami perhaps has greater institutional coordination and high levels of public outreach and discussion, but Venice has displayed greater long-term efforts at all governmental levels. The adaptation measures must be well-coordinated at all institutional levels and based on principles of good governance (transparency, public participation, efficiency, equity, lack of corruption).

\section{Policy Recommendations}

From our examination of the cases of SLR adaptation in Venice and Miami, we offer the following policy recommendations:

1. Plan for Redundancy. Coastal cities should not rely soley on one intervention, but must adopt numerous measures that may appear redundant. Nature-based adaptation measures, such as coastal wetland creation and enhancement, as well as optimal hydrological management, must be important components of the package (Tobey et al. 2010; Fernandino et al. 2018).

2. Adopt Long-Term Planning Horizons. Venice and Miami should take climate change and long-term planning into greater account and use it to create a greater sense of shared responsibility about the future. Distant futures of 30 or 50 years are beyond the normal planning period for governments, developers, the insurance industry, or homeowners, but good coastal management in light of climate change requires this longer planning horizon (Tobey et al. 2010). Moreover, uncertainty exists with respect to the extent of the vulnerability and possible impacts (Spence et al. 2012, Weber 2016; Treuer et al. 2018). Despite uncertainties about the rate of SLR, vulnerable coastal cities need to address rising seas "yesterday". Delay will only close options, lead to greater losses, and result in greater future costs.

3. Utilize Principles and Methodologies of Integrated Coastal Management (ICM). Long-term decisions must integrate systems - economic, environmental, social, and institutional. In a sense this calls for the principles and strategies of Integrated Coastal Management. This is necessary so governments and the private sector can examine their investment decisions spatially. ICM facilitates coordination among economic sectors and the authorities that regulate them ("sectoral integration"), as well as cooperation between different governmental levels ("vertical integration"). ICM also demands broad stakeholder participation in the decision-making process.

4. Monitor Social Impacts. We must carefully track to societal impacts of SLR. In Miami, SLR may increase competition for lower-valued properties at higher elevations, thus making it more difficult for socially vulnerable groups to respond to SLR and potentially displacing them. The gentrification of the historic center of Venice is partly due to the expenses involved in adapting to flooding. This raises the issue of "climate justice". 
5. Utilize Adaptive Management. As the many uncertainties lessen (SLR rate, location, timing, success of adaptation measures, ecosystem repsonses, population growth, hurricane and storm surge incidents, etc.), adaptation planning and projects must be flexible and altered as necessary to take into account new information and changed circumstances..

6. Integrate Ecosystem-based Natural Adaptive Approaches. In South Florida, Everglades restoration plans must integrate climate change impacts with an adaptive management strategy to provide benefits for coastal ecosystems to counteract SLR impacts. Potentially some options will couple with SLR adaptive response in MDC, such as increasing freshwater flow to support coastal mangrove forests as important buffers against SLR and protect peat soils and to control groundwater levels and saltwater intrusion. Similarly, the Venice experience once emphasized wetland creation as a means to address SLR. In short, societies must utilize ecosystem-based approaches when adapting to SLR - considering the wider regional ecosystem impacts to implemented measures and the contributions that the ecosystems themselves can offer.

7. Create scientific information in vehicles that the public can clearly understand. Credible scientific information to reduce the range of uncertainty (SLR rates, locations, timeframe) will increase political motivation to act and decrease opposition to overadaptation.

8. Evaluate the success of adaptation measures. After investing funds and efforts to implement adaptation plans and actions, we must evaluate whether they have been successful. This will indicate whether plans and actions need to be altered to increase likelihood of success.

9. Critically evaluate the ecosystem impacts of large-scale "high tech" solutions. Often large-scale expensive technologically-based solutions (MoSE and the Central and South Florida Project for Flood Control) cause the loss of ecological resilience and cause an ecological crisis. These "solutions" must integrate the latest climate change information, and decisionmakers must understand their environmental costs. 


\section{References}

Ammerman AJ, McClennen CE (2000) Saving Venice. Science 289:1301-1302

Antonioli F, M Anzidei A, Amorosi V, Lo Presti G, Mastronuzzi G, Deiana G, De Falco G, Fontana A, Fontolan G, Lisco S, Marsico A, Moretti M, Orrù PE, Sannino GM, Serpelloni E, Vecchio A (2017. Sealevel rise and potential drowning of the Italian coastal plains: Flooding risk scenarios for 2100. Quaternary Science Reviews 158:29-43 https://doi.org/10.1016/j.quascirev.2016.12.021

Araos M, Berrang-Ford L, Ford JD, Austin SE, Lesnikowski A (2016) Climate change adaptation planning in large cities: A systematic global assessment. Environmental Science \& Policy 66:375-382. https://doi.org/10.1016/j.envsci.2016.06.009

Ariza E, Lindeman KC, Mozumder P, Suman DO (2014) Beach management in Florida: Assessing stakeholder perceptions on governance. Ocean \& Coastal Management 96:82-93. https://doi.org/10.1016/j.ocecoaman.2014.04.033

Aumen NG, Havens KE, Best GR, Berry L (2015) Predicting ecological responses of the Florida Everglades to possible future climate scenarios: Introduction. Environmental Management 55:741-748.

Banks KW, Riegl BM, Shinn EA, Piller WE, Dodge RE (2007) Geomorphology of the southeast Florida continental reef tract (Miami-Dade, Broward, and Palm Beach Counties, USA). Coral Reefs 26:617-633

Bloetscher F, Romah T (2015) Tools for assessing sea level rise vulnerability. Journal Water Climate Change 6:181-190

Bloetscher F, Polsky C, Bolter K, Mitsova D, Palbicke Garces K, King R, Carballo IC, Hamilton K (2016) Assessing potential impacts of sea level rise on public health and vulnerable populations in Southeast Florida and providing a framework to improve outcomes. Sustainability 8:315. doi:10.3390/su8040315

Bock Y, Wdowinski S, Ferretti A, Novali F, Fumagalli A (2012) Recent subsidence of the Venice Lagoon from continuous GPS and interferometric synthetic aperture radar. Research Letter. https://doi.org/10.1029/2011GC003976

Butler WH, Deyle RE, Mutnansky C (2016) Low-regrets incrementalism: Land use planning adaptation to accelerating sea level rise in Florida's coastal communities. Journal of Planning Education and Research 36(3):319-332

Camuffo D, Bertolin C, Schenal P (2017) A novel proxy and the sea level rise in Venice, Italy, from 1350 to 2014. Climatic Change. 143:73-86. http://doi 10.1007/s10584-017-1991-3

Caniato G (2005) Between salt and fresh water. In: Fletcher CA, Spencer T (eds.), Flooding and environmental challenges for Venice and its lagoon: state of knowledge. Cambridge University Press, London UK, pp 7-14

Carbognin L, Teatini P, Tomasin A, Tosi L (2009) Global change and relative sea level rise at Venice: what impact in term of flooding. Clim Dyn. http:// doi 10.1007/s00382-009-0617-5

Carraro C, Sgobbi A (2008) Climate Change Impacts and Adaptation Strategies In Italy. An Economic Assessment. FEEM Nota di Lavoro 6, 28 pp

Church JA, Clark PU, Cazenave A, Gregory JM, Jevrejeva S, Levermann A, Merrifield M, Milne G, Nerem R, Nunn P et al. (2013) Sea Level Change. PM Cambridge University Pres, Cambridge, UK,

Comerlati A, Ferronato M, Gambolati G, Putti M, Teatini P, (2003) Can CO2 help save Venice from the sea?

831 Comerlati A, Ferronato M, Gambolati G, Putti M,Teatini P (2004) Saving Venice by sea water. J. Geophys. 
Corcoran, WT, Johnson E (2005) Climate of North America. In: Oliver JE (ed), Encyclopedia of World Climatology, Springer, Dordrecht, The Netherlands, pp. 525-534

De Sherbinin A, Schiller A, Pulsipher A (2007) The vulnerability of global cities to climate hazards. Environment \& Urbanization 19(1): 39-64, https://doi.org/10.1177/0956247807076725

De Conto RM, Pollard D (2016) Contribution of Antarctica to past and future sea-level rise. Nature 531:591597, https://doi.org/10.1038/nature17145

Fagherazzi S, Carniello L, D'Alpaos L, Defina A (2006) Critical bifurcation of shallow microtidal landforms in tidal flats and salt marshes. In: Proc. of the National Academy of Sciences of the United States of America, PNAS 103(8337): 8337-8341. https://doi.org/doi.org/10.1073/pnas.0508379103

Favero G (2014) Venezia dopo Venezia: economia e demografia urbana nel novecento (in italian). Laboratoire Italien 15:79-89

Fernandino G, Elliff CI, Silva IR (2018) Ecosystem-based management of coastal zones in face of climate change impacts: Challenges and inequalities. Journal of Environmental Management 215:32-39, https://doi.org/10.1016/j.jenvman.2018.03.034

Flavelle C (2017) The nightmare scenario for Florida's coastal homeowners. Bloomberg News. https://www.bloomberg.com/news/features/2017-04-19/the-nightmare-scenario-for-florida-s-coastalhomeowners

Fiaschi S, Wdowinski S (2016) The contribution of land subsidence to the increasing coastal flooding hazard in Miami Baeach. 2nd International Workshop on Coastal Subsidence May 30 - June 1, 2016- Venice (Italy).

Finkl CW, Warner MT (2005) Morphologic Features and Morphodynamic Zones along the Inner Continental Shelf of Southeastern Florida: An Example of Form and Process Controlled by Lithology. Journal of Coastal Research, Special Issue 42:79-96

Finkl CW, Restrepo-Coupe N (2007) Potential natural environments based on pedological properties in the coastal conurbation of subtropical southeast Florida. J Coast Res 23 (2):317-349

Finkl CW, Andrews JL (2008) Shelf geomorphology along the southeast Florida Atlantic continental platform: Barrier coral reefs, nearshore bedrock, and morphosedimentary features. Journal of Coastal Research, 24(4): 823-849

Finkl CW (2014) East Florida's Barrier Islands: Natural vs. Man-Made. http://coastalcare.org

Fletcher CA, Spencer T (2005) Flooding and Environmental Challenges for Venice and its Lagoon: State of Knowledge. Cambridge University Press

Fleming E, Payne J, Sweet W, Craghan M, Haines J, Hart JF, Stiller H, Sutton-Grier A (2018) Coastal effects. In: Reidmiller DR, Avery CW, Easterling RD, Kunkel KE, Lewis KLM, Maycock TK, Stewart BC (eds). Impacts, Risks, and Adaptation in the United States: Fourth National Climate Assessment, Volume II. U.S. Global Change Research Program, Washington, DC, USA, pp. 322-352. https://doi.org/10.7930/NCA4.2018.CH8

Foster AB (1983) Biscayne National Park. In: Harris A and Tuttle E (eds) Geology of National Parks. Kendall/Hunt Publishing Company: Dubuque, Iowa, pp. 443-452

Fu X, Gomaa M, Deng Y, Zhong-Ren P (2017) Adaptation planning for sea level rise: A study of US coastal cities. Journal of Environmental Planning and Management 60(2):249-265. https://doi.org/10.1080/09640568.2016.1151771 
Gambolati G, Teatini P, Ferronato M, Strozzi T, Tosi L, Putti M (2009) On the uniformity of anthropogenic Venice uplift. Terra Nova, 21:467-473. http://doi:10.1111/j.1365-3121.2009.00903.x

Ghose T (2013) The 20 Cities Most Vulnerable to Flooding. Live Science.

Goodell J (2017) The Water Will Come: Rising Seas, Sinking Cities, and the Remaking of the Civilized World. Little, Brown, and Company, New York

Grunwald M (2007) The Swamp: The Everglades, Florida, and the Politics of Paradise. Simon and Schuster, New York

Hallengatte S, Green C, Nicholls RJ, Corfee-Morlot J (2013) Future flood losses in major coastal cities. Nat. Clim. Change 3:802-806. https://doi.org/10.1038/nclimate1979

Hanson S, Nichols R, Ranger N, Hallegarte S, Corfee-Morlot J, Herweijer C, Chateau C (2011) A global ranking of port cities with high exposure to climate extremes. Climate Change 104:89-111

Hauer ME, Evans JM, Mishra DR (2016) Millions projected to be at risk from sea-level rise in the continental United States. Nature Climate Change 6:691-695

Hay CC, Morrow E, Kopp RE, Mitrovica JX (2015) Probabilistic reanalysis of twentieth-century sea-level rise. Nat. Clim. Change. 517:481-484.

Hoffmeister JE (1982) Land from the Sea: the Geologic Story of South Florida. University of Miami Press, Coral Gables, Florida

Hughes JD, White JT (2016) Hydrologic conditions in urban Miami-Dade County, Florida, and the effect of groundwater pumpage and increased sea level rise on canal leakage and regional groundwater flow (Version 1.2, July 2016). U.S. Geological Survey Scientific Investigations Report 2014-5162. 175 pp. http://dx.doi.org/10.3133/sir20145162

Idealista (2015) Indice annuale 2015 dei prezzi delle abitazioni di seconda mano (2015 annual price index for second-hand housing). https://st3.idealista.it/news/archivie/2015-12/indice_annuale_prezzi_2015.pdf.

Indirli M, Knezic S, Borg RP, Kaluarachchi Y, Ranguelov B, Romagnoli F, Rochas C (2014) The ANDROID case study; Venice and its territory: a general overview. Procedia Economics and Finance 18:837-848. https://doi.org/10.1016/S2212-5671(14)01009-0

IPCC (2014) Climate Change 2014: Synthesis Report. Contribution of Working Groups I, II and III to the Fifth Assessment Report of the Intergovernmental Panel on Climate Change [Core Writing Team Pachauri RK, Meyer LA (eds)]. IPCC, Geneva, Switzerland, pp. 151

Kaluarachchi Y, Indirli M, Ranguelov B, Romagnoli F (2014) The ANDROID case study; Venice and its territory: existing mitigation options and challenges for the future. Procedia Economics and Finance 18:815-824. https://doi.org/10.1016/S2212-5671(14)01007-7

Keahey J (2002) Venice Against the Sea: A City Besieged. St. Martin's Press

Keim BD, Muller RA, Stone GW (2007) Spatiotemporal patterns and return periods of tropical storm and hurricane strikes from Texas to Maine. Journal of Climate 20:3498-3509

Kirwan ML, Megonigal JP (2013) Tidal wetland stability in the face of human impacts and sea-level rise. Nature 504:53-60. https://doi.org/10.1038/nature12856

Koch MS, Coronado C, Miller MW, Rudnick DT, Stabenau E, Halley RB, Sklar FH (2015) Climate change projected effects on coastal foundation communities of the Greater Everglades using a 2060 scenario: Need for a new management paradigm. Environmental Management 55:857-875. https://doi.org/10.1007/s00267- 
914 Kopp RE, Kemp AC, Bittermann K, Horton BP, Donnelly JP, Gehrels WR, Hay CC, Mitrovica JX, Morrow 915 ED, Rahmstorf S (2016) Temperature-driven global sea-level variability in the Common Era. In: Proceedings of the National Academy of Sciences 113, E1434-E1441. http://www.pnas.org/content/113/11/E1434.

918 Korten T (2015) Gov. Rick Scott's ban on climate change term extended to other state agencies. Miami Herald, 919 March 11, 2015.

920 Kulp S, Strauss BH (2017) Rapid escalation of coastal flood exposure in US municipalities from sea level rise. 921 Climate Change 142:477-489

Juhola S, Westerhoff L (2011) Challenges of adaptation to climate change across multiple scales: a case study of network governance in two European countries. Environmental Science \& Policy 14:239-247

Lambeck K, Antonioli F, Anzidei M, Ferranti L, Leoni G, Scicchitano G, Silenzi S (2011) Sea level change along the Italian coast during the Holocene and projections for the future. Quaternary International 232:250257

Lentz EE, Thieler ER, Plant NG, Stippa SR, Horton RM, Gesch DB (2016) Evaluation of dynamic coastal response to sea-level rise modifies inundation likelihood. Nature Climate Change 6:696-701. https://doi.org/ 10.1038/NCLIMATE2957

Lodge TE (2010) The Everglades Handbook: Understanding the Ecosystem. CRC Press, Boca Raton, Florida.

Magill B (2017) Miami taxpayters asked to foot the bill to protect the city from climate change. Climate Liability. https://www.climateliabilitynews.org/2017/08/16/miami-florida-climate-change-sea-level-riseadaptation/

934 Malmstadt JC, Elsner JB, Jagger TH (2019) Risk of strong hurricane winds to Florida cities. Journal of Applied Meteorology and Climatology 49:2121-2132

936 Mancuso F (2014) Building on Water: The surprising expedients that made possible the birth and growth of Venice. Corte del Fontego Editore, Venice

Marsico A et al (2017) Flooding scenario for four Italian coastal plains using three relative sea level rise models. Journal of Maps 13(2): 961-967. https://doi.org/10.1080/17445647.2017.1415989

940 Maul GA, (2008) Florida's Changing Sea Level in Shoreline.The Florida Beach and Shore Preservation Society. http://www.fsbpa.com/documents/0508Shoreline.pdf

MAV-CVN (2013) Gestione sostenibile dell'identità lagunare veneziana (Sustainable management of the Venetian lagoon identity), C.1. 14, Doc. 70786-REL-T003. 0., 230 pp

Maxwell K, Julius S, Grambsch A, Kosmal A, Larson L, Sonti N (2018) Built environment, urban systems, and cities. In: Reidmiller DR, Avery CW, Easterling DR, Kunkel KE, Lewis KLM, Maycock TK, Stewart BC (eds). Impacts, Risks, and Adaptation in the United States: Fourth National Climate Assessment, Volume II, U.S. Global Change Research Program, Washington, DC, USA, pp. 438-478. https://doi.org/10.7930/NCA4.2018.CH11

Melillo JM, Richmond TTC, Yohe GW, EDS (2014) Climate Change Impacts in the United States: The Third National Climate Assessment. U.S. Global Change Research Program.https://doi:10.7930/J0Z31WJ2
Miami-Dade
County
(2014a)
Climate Change
Action
Plan. https://www.miamidade.gov/greenprint/pdf/climate_action_plan.pdf 
Miami-Dade County (2014b) Sea Level Rise Task Force Report and Recommendations. http://www.miamidade.gov/planning/library/reports/sea-level-rise-report-recommendations.pdf.

Miami-Dade County. Department of Regulatory and Economic Resources. (2017). Adopted Components: Comprehensive Development Master Plan for Miami-Dade County, Florida. https://www.miamidade.gov/planning/cdmp-adopted.asp

Milne GA, Gehrels WR, Hughes CW, Tamisiea ME (2009). Identifying the causes of sea-level change. Nat. Geosci. 2:471-478

Molinaroli E, Guerzoni S, De Falco G, Sarretta A, Cucco A, Como S, Simeone S, Perilli A, Magni P (2009a) Relationships between hydrodynamic parameters and grain size in two contrasting transitional environments: The Lagoons of Venice and Cabras, Italy. Sedimentary Geology 219:196-207

Molinaroli E, Guerzoni S, Sarretta A, Masiol M, Pistolato M (2009b) Thirty-year changes (1970-2000) in bathymetry and sediment texture recorded in the lagoon of Venice sub-basins, Italy. Marine Geology 258, $115-125$

Munaretto S, Huitema D (2012) Adaptive comanagement in the Venice lagoon? An analysis of current water and environmental management practices and prospects for change. Ecology and Society 17(2):19. http://dx.doi.org/10.5751/ES-04772-170219

National Hurricane Center (2019) Estimated return period in years for hurricanes passing within 50 nautical miles of various locations on the U.S. coast. https://www.nhc.noaa.gov/climo/\#cp100

NRDC (National Academy of Sciences) (2012) Disaster Resilience: A National Imperative, The National Academies Press,Washington, D.C. https://doi.org/10.17226/13457.

Neumann JE, Emanuel K, Ravela S, Ludwig L, Kirshen P, Bosma K, Martinich J (2015) Joint effects of storm surge and sea-level rise on US Coasts: New economic estimates of impacts, adaptation, and benefits of mitigation policy. Climate Change 129:337-349

Nicholls RJ, Hanson S, Herweijer C, Patmore N, Hallegatte S, Corfee-Morlot J, Chateau J, Muir-Wood R (2007) Ranking of the world's cities most exposed to coastal flooding today and in the future. OECD Environment Working Paper No. 1 (ENV/WKP(2007)1).

Nicholls RJ (2011) Planning for the impacts of sea level rise. Oceanography 24(2):144-157. https://doi.org/10.5670/oceanog.2011.34

NOAA/AOML (Atlantic Oceanographic and Meteorological Laboratory) (2009) All U.S. Hurricanes (18512008). Miami:, http://www.aoml.noaa.gov/hrd/hurdat/ushurrlist18512008.txt, accessed August 2016

Nungesser M, Saunders C, Coronado-Molina C, Obeysekera J, Johnson J, McVoy C, Benscoter B (2015) Potential effects of climate change on Florida's Everglades. Environmental Management 55:824-835

Obeysekera J, Browder J, Hornung L, Harwell MA (1999) The natural South Florida system I: Climate, geology, and hydrology. Urban Ecosystems 3:223-244

Obeysekera J, Barnes J, Nungesser M (2015) Climate sensitivity runs and regional hydrologic modeling for predicting the response of the Greater Florida Everglades Ecosystem to climate change. Environmental Management 55:749-762. https://doi.org/10.1007/s00267-014-0315-x [physics.geo-ph] https://arxiv.org/ftp/arxiv/papers/1406/1406.2821.pdf 
Passeri DL, Hagen SC, Medeiros SC, Bilskie MV, Alizad K, Wang D (2015) The dynamic effects of sea level rise on low-gradient coastal landscapes: A review, Earth's Future. 3:159-181. https://doi.org/10.1002/2015EF000298

Patricola CM, Wehner MF (2018) Anthropogenic influences on major tropical cyclone events. Nature 563:339346. https://doi.org/10.1038/s41586-018-0673-2

Pfeffer WT, Harper JT, Neel SO (2008) Kinematic constraints on glacier contribution to $21^{\text {st }}$-century sea-level rise. Science 321(5894)1340-1343. https://doi.org/10.1126/science.1159099

Pilkey OH, Dixon KL (1996) The Corps and the Shore. Island Press, Washington, D.C.

Pielke RA, Gratz J, Landsea CW, Collins D, Saunders MA, Musulin R (2008) Normalized hurricane damages in the United States: 1900-2005. Natural Hazards Review 29(1):29-42.

Precht WF, Miller SL (2007) Ecological Shifts along the Florida Reef Tract: The Past as a Key to the Future. In Geological Approaches to Coral Reef Ecology, (ed. R. B. Aronson) Springer, Berlin, 237-312

1004

Rahmstorf S, Foster G, Cazenave A (2012) Comparing climate projections to observations upto 2011. Environ.

Rahmstorf S, Box JE, Feulner G, Mann ME, Robinson A, Rutherford S, Schaffernicht E (2015) Exceptional twentieth-century slowdown in Atlantic Ocean overturning circulation. Nature Climate Change, 5:475-480. http://doi. 10.1038/NCLIMATE2554

Ramieri E, Hartley A, Barbanti A, Duarte Santos F, Gomes A, Hilden M, Laihonen P, Marinova N, Santini M (2011) Methods for assessing coastal vulnerability to climate change, European Topic Centre on Climate Change Impacts, Vulnerability and Adaptation (ETC CCA) Technical Paper, Bologna (IT), p 93.

Rao K (2016) Climate change and housing: Will a rising tide sink all homes? Zillow document. Zillow Research. https://www.zillow.com/research/climate-change-underwater-homes-12890/

Roggero M, Fritsch O (2010) Mind the Costs: Rescaling and Multi-Level Environmental Governance in Venice Lagoon. Environmental Management 46:17-28. https://doi.org/10.1007/s00267-010-9449-7

Rusconi A (2016) La gestione della laguna con la soppressione del Magistrato alle Acque. In: Salvaguardia domani, oltre il MOSE. Sala S.Leonardo 4/11/2016 (in italian).

Sarretta A, Pillon S, Molinaroli E, Guerzoni S, Fontolan G (2010) Sediment budget in the Lagoon of Venice, Italy. Continental Shelf Research 30:934-949. https://doi.org/10.1016/j.csr.2009.07.002

SFWMD (2018) 2018 Lower East Coast Water Supply Plan Update. Available at: https://www.sfwmd.gov/sites/default/files/documents/2018_lec_plan_planning_doc.pdf

Sklar FH, Chimney MJ, Newman S, McCormick P, Gawlik D, Miao SL, McVoy C, Said W, Newman J, Coronado C, Crozier G, Korvela M, Rutchey K (2005). The ecological-societal underpinnings of Everglades restoration. Front. Ecol. Environ. 3(3):161-169

Smiley D (2017) Miami gets \$200 million to spend on sea rise as voters pass Miami Forever bond. Miami Herald. http://www.miamiherald.com/news/politics-government/election/article183336291.html

Southeast Florida Regional Climate Change Compact Counties (2012) A Region Responds to a Changing Climate: Regional Climate Action Plan.

Spence A, Poortinga W, Pidgeon N (2012) The psychological distance of climate change. Risk Analysis $32: 957-972$ 
Stammer D (2008) Response of the global ocean to Greenland and Antarctic ice melting. J. Geophys. Res. 113: C06022. http://doi:10.1029/2006JC004079

Suburban Stats. 2018. https://suburbanstats.org/population/florida/list-of-counties-and-cities-in-florida\#CK

Suman D, Guerzoni S, Molinaroli E (2005) Integrated coastal management in the Venice lagoon and its watershed. Hydrobiologia 550:251-269

Sweet W, Kopp R, Weaver C, Obeysekera J, Horton R, Thieler ER, Zervas C (2017) Global and Regional Sea Level Rise Scenarios for the United States. Silver Spring, Maryland

Teatini P, Tosi L, Strozzi T, Carbognin L, Cecconi G, Rosselli R, Libardo S (2012) Resolving land subsidence within the Venice Lagoon by persistent scatterer SAR interferometry. Physics and Chemistry of the Earth $40-41: 72-79$

Thead EA (2016) Sea level rise: Risk and resilience in coastal cities. The Climate Institute http://climate.org/wp-content/uploads/2016/10/Erin-Sea-levels.pdf

Tobey J, Rubinoff P, Robadue D, Ricci G, Volk R, Furlow J, Anderson G (2010) Practicing coastal adaptation to climate change: Lessons from integrated coastal management. Coastal Management 38:317-335

Torresan S, Critto A, Rizzi J, Marcomini A (2012) Assessment of coastal vulnerability to climate change 1046 hazards at the regional scale: the case study of the North Adriatic Sea. Nat Hazards Earth Syst Sci 12(7):2347-2368

Tosi L, Teatini P, Strozzi T (2013) Natural versus anthropogenic subsidence of Venice Scientific Reports.| 3:2710. http://doi: 10.1038/srep02710

Tosi L, Teatini P, Strozzi T, Da Lio C (2014) Relative land subsidence of the Venice coastland, Italy. Engineering Geology for Society and Territory 4:171-173

Treuer G, Broad K, Meter R (2018) Using simulations to forecast homeowner response to sea level rise in South Florida: Will they stay or will they go? Global Climate Change 48:108-118

Trincardi F, Barbanti A, Bastianini M, Benetazzo A, Cavaleri L, Chiggiato J, Papa A, Pomaro A, Sclavo M, Tosi L, Umgiesser G (2016) The 1966 flooding of Venice: What time taught us for the future. Oceanography 29(4):178-186. https://doi.org/10.5670/oceanog.2016.87.

1057

Umgiesser G, Matticchio B (2006) Simulating the mobile barrier (MOSE) operation in the Venice Lagoon, Italy: global sea level rise and its implication for navigation. Ocean Dynamics 56: 320-332. https://doi.org/10.1007/s10236-006-0071-4

UCS (Union of Concerned Scientists) (2017). Encroaching Tides in Miami-Dade County, Florida, UCS Fact Sheet, pp 1-10. https://www.ucsusa.org/sites/default/files/attach/2016/04/miami-dade-sea-level-rise-tidalflooding-fact-sheet.pdf

UNESCO (2015) Report of the joint World Heritage Centre/ICOMOS/Ramsar Reactive Monitoring mission to the property of Venice and its Lagoon (Italy), 13-18 October 2015

UNISDR (2009) Terminology on Disaster Risk Reduction, United Nations International Strategy for Disaster Reduction, Geneva. https://www.unisdr.org/files/7817_UNISDRTerminologyEnglish.pdf

Valle-Levinson A, Dutton A, Martin JB (2017) Spatial and temporal variability of sea level rise hot spots over the eastern United States, Geophys. Res. Lett. 44:7876-7882. doi:10.1002/2017GL073926

Varrani A, Nones M (2017) Vulnerability, impacts and assessment of climate change on Jakarta and Venice. 1070 International Journal of River Basin Management. https://doi.org/10.1080/15715124.2017.1387125 
1071 Vergano L, Nunes P (2007) Analysis and evaluation of ecosystem resilience: an economic perspective with an application to the Venice lagoon. Biodivers. Conserv 16:3385-3408. https://doi.org/10.1007/s10531-0069085-Vergano L, Umgiesser G. Nunes P (2010) An economic assessment of the impact of the MOSE barriers on Venice port activity. FEEM Sustainable Development Series, Report 17/2010 35 pp.

Vermeer M, Rahmstorf S (2009) Global sea level linked to global temperature. Proc. Natl. Aca. Sci. 106:51

Wachinger G, Renn O, Begg C, Kuhlicke C (2013). The risk perception paradox - Implications for governance and communication of natural hazards. Risk Analysis 33:1049-1065

Wanless HR, Parkinson RW, Tedesco LP (1994) Sea level control on stability of wetlands. In: Davis SM, Ogden JC (eds). Everglades: The Ecosystem and Its Restoration. Delray Beach, Florida: St. Lucie Press, pp. 199-223.

Wdowinski S, Bray R, Kirtman BP, Wu Z (2016) Increasing flooding hazard in coastal communities due to rising sea level: Case study of Miami Beach, Florida. Ocean \& Coastal Management 126:1-8

Weber EU (2016) What shapes perceptions of climate change? New research since 2010. Wiley Interdisciplinary Rev. Climate Change 7:125-134. https://doi.org/10.1002/wcc.377

Weiss JL, Overpeck JT, Strauss B (2011) Implications of recent sea level rise science for low-elevation areas of coastal cities of the conterminous U.S.A. Climate Change 105:635-645.

Zaggia L, Lorenzetti G, Manfè G, Scarpa GM, Molinaroli E, Parnell KE, Rapaglia JP, Gionta M, Soomere T (2017) Fast shoreline erosion induced by ship wakes in a coastal lagoon: Field evidence and remote sensing analysis. PLoS One 12: 1-23. https://doi.org/10.1371/journal.pone.0187210

Zanuttigh B (2011) Coastal flood protection: What perspective in a changing climate? The THESEUS Approach, Environmental Science and Policy 14:845-863. https://doi.org/10.1016/j.envsci.2011.03.015

Zervas C (2009) Sea Level Variations of the United States 1854-2006. NOAA Technical Report NOS CO-OPS 053, 75p, Appendices A-E. https://tidesandcurrents.noaa.gov/publications/Tech_rpt_53.pdf 
1098 Fig. 1 Coastal areas of Venice Lagoon (a) and Miami-Dade County (b).

1099 Fig. 2 Graphic of historic and future sea-level trends in the Venice area. The assessed likely range is shown as a shaded band. Observed data from: Comune di Venezia, Centro Previsioni e Segnalazioni Maree. Projections data from: IPCC, 2014

Fig. 3 Graphic of historic and future sea-level trends in Miami Dade County. The assessed likely range is shown as a shaded band. Observed data from: https://tamino.wordpress.com/2018/04/29/sea-level-onthe-u-s-east-coast/. Projections data from: http://sealevel.climatecentral.org/ssrf/florida

Fig. 4 Flooding scenario of lands adjacent to the Venice Lagoon using three relative SLR models (adapted from Marsico et al. 2017)

Fig. 5 The map (a) indicates depth of flooding in MDC from a storm surge associated with a Category 3 hurricane with no SLR. The map (b) indicates depth of flooding in MDC from a storm surge associated with a Category 3 hurricane and SLR of $0.60 \mathrm{~m}$. Maps are based on the Sea, Lake, and Overland Surges from Hurricanes (SLOSH) surge model used by the National Hurricane Center. (modified from: Fig. 2., Miami-Dade County, 2014b; maps prepared by Dr. Keren Bolter).

1112 Fig. 6 The new institutional setting in Venice and their relationships.

1113 Fig. 7 The institutional setting in Miami-Dade County. 
Table 1 Comparison of basic attributes of the two study areas.

\begin{tabular}{|l|c|c|}
\hline & $\begin{array}{c}\text { Venice Lagoon and } \\
\text { Surrounding Areas }\end{array}$ & $\begin{array}{c}\text { Biscayne Bay and } \\
\text { Surrounding Areas }\end{array}$ \\
\hline Total Area $\left(\mathrm{km}^{2}\right)$ & 550 & 1,111 \\
\hline Mean Depth $(\mathrm{m})$ & 1.2 & 2 \\
\hline Tidal Range $(\mathrm{m})$ & 0.7 & 1.0 \\
\hline Average Elevation $(\mathrm{m})$ & 1.5 & 1.6 \\
\hline Population of Lagoonal Cities $\left(10^{3}\right)$ & 55 & 2,600 \\
\hline Population on Mainland $\left(10^{3}\right)$ & 180 & 2,000 \\
\hline Average Housing Value $\left(\mathrm{USD} / \mathrm{m}^{2}\right)$ & 5,000 & 22.5 \\
\hline Annual Number of Tourists $\left(10^{6}\right)$ & 30 & 5.3 \\
\hline Annual Number of Cruise Tourists $\left(10^{6}\right)$ & 2 & \\
\hline
\end{tabular}


Table 2 Adaptation to flooding (Venice)

\begin{tabular}{|c|c|c|c|}
\hline \multicolumn{3}{|c|}{ Venice } & \multirow[b]{2}{*}{ Transferability } \\
\hline Realized & Pros & Cons & \\
\hline $\begin{array}{l}\text { 1700: Construction of walls } \\
\text { "murazzi" (walls made of cemented } \\
\text { rocks). }\end{array}$ & $\begin{array}{l}\text { Protection of the lagoon } \\
\text { and the city against the } \\
\text { sea }\end{array}$ & $\begin{array}{l}\text { The barrier system has been } \\
\text { tightened }\end{array}$ & --- \\
\hline $\begin{array}{l}\text { 1970s: A network of walkways is } \\
\text { installed along the main pedestrian } \\
\text { routes. }\end{array}$ & $\begin{array}{l}\text { Pedestrian mobility } \\
\text { around the city; }\end{array}$ & None & YES \\
\hline $\begin{array}{l}\text { 1980s: The protection of ground } \\
\text { floors, adaptation of electrical } \\
\text { systems, and placement of steel } \\
\text { barriers at the entrance to buildings }\end{array}$ & $\begin{array}{l}\text { The strong awareness of } \\
\text { its citizens to adopt } \\
\text { adaptation measures to } \\
\text { protect their assets }\end{array}$ & None & YES \\
\hline $\begin{array}{l}\text { 1984: Interventions from Special } \\
\text { Law: } \\
\text { 1) restoration of the murazzi (sea- } \\
\text { walls); } \\
\text { 2) nourishment of eroded beaches; } \\
\text { 3) prohibition of methane extraction } \\
\text { and drilling of new artesian wells; } \\
\text { 4) elevation of low-lying parts of } \\
\text { the urban center; } \\
\text { 5) dredging of internal Venice } \\
\text { canals. } \\
\text { 6) Wetland creation; }\end{array}$ & $\begin{array}{l}\text { Protection of inhabitants } \\
\text { of Pellestrina and Lido } \\
\text { and the historic city } \\
\text { against the sea }\end{array}$ & $\begin{array}{l}\text { After } 1998 \text { there was not } \\
\text { enough money to comply } \\
\text { with the intervention for (1) } \\
\text { (2) and (5) every } 10 \text { years, as } \\
\text { planned. }\end{array}$ & $\begin{array}{l}\text { (1), (3) Not } \\
\text { suitable, but } \\
\text { possible in other } \\
\text { cities } \\
\text { (2) YES, but in } \\
\text { Miami worked } \\
\text { better } \\
\text { (4) YES } \\
\text { (5) YES } \\
\text { (6) YES } \\
\text { (mangroves and } \\
\text { seagrass beds) }\end{array}$ \\
\hline $\begin{array}{l}\text { 1994-1998: Public paved areas are } \\
\text { being raised, to defend against tides } \\
\text { up to } 100-110 \mathrm{~cm} .\end{array}$ & $\begin{array}{l}\text { Commercial activities } \\
\text { and cultural heritage of } \\
\text { the city are protected }\end{array}$ & None & YES \\
\hline $\begin{array}{l}\text { 2003: MoSE (Experimental } \\
\text { Electromechanical Module) } \\
\text { expected to be completed 2020- } \\
2022\end{array}$ & $\begin{array}{l}\text { Flood protection in case } \\
\text { of waters higher than } 120 \\
\mathrm{~cm}(\sim 10 \text { episodes/yr })\end{array}$ & $\begin{array}{l}\text { Not working between } 90-110 \\
\mathrm{~cm} \text { (40-50 episodes/year) } \\
\text { 1) The majority of funding } \\
\text { has been dedicated to the } \\
\text { MoSE project. Measures } \\
\text { previously implemented } \\
\text { (wetland creation and beach } \\
\text { nourishment) were halted. } \\
\text { 2) The mobile barriers are } \\
\text { producing changes in the } \\
\text { structure of the lagoon inlets, } \\
\text { with consequences for the } \\
\text { dynamics of the lagoon } \\
\text { ecosystem. } \\
\text { 3) Additional annual costs for } \\
\text { the interruption of ship traffic } \\
\text { due to the operation of the } \\
\text { MoSE }\end{array}$ & $\begin{array}{l}\text { Not suitable for } \\
\text { Miami; the } \\
\text { geological setting } \\
\text { of the city and } \\
\text { vulnerability to } \\
\text { hurricane storm } \\
\text { surges make the } \\
\text { adoption of mobile } \\
\text { sea barriers similar } \\
\text { to MoSE } \\
\text { impractical. } \\
\text { Possible in other } \\
\text { cities. }\end{array}$ \\
\hline $\begin{array}{l}\text { 2005: Flood information by alarms } \\
\text { in real time via web and smartphone }\end{array}$ & $\begin{array}{l}\text { protection of commercial } \\
\text { activities }\end{array}$ & None & YES \\
\hline \multicolumn{4}{|l|}{ Recommendations \& Future } \\
\hline Elevation of St. Mark's Square & $\begin{array}{l}\text { Protection of the Historic } \\
\text { Square }\end{array}$ & Not yet implemented & Very difficult \\
\hline $\begin{array}{l}\text { 2016: Veneto Regional } \\
\text { Government. Integrated } \\
\text { management of the coastal zone } \\
\text { (ICZM): Study and monitoring for } \\
\text { the definition of the interventions to } \\
\text { protect the coasts from erosion in } \\
\text { the Veneto Region (guidelines) }\end{array}$ & $\begin{array}{l}\text { Comprehensive Plan: } \\
\text { includes climate change } \\
\text { adaptation measures }\end{array}$ & Not yet implemented & YES \\
\hline
\end{tabular}


Table 3 Adaptation to Flooding (Miami)

\begin{tabular}{|c|c|c|c|}
\hline \multicolumn{3}{|c|}{ Miami } & \multirow[b]{2}{*}{ Transferability } \\
\hline Realized & Pros & Cons & \\
\hline $\begin{array}{l}1926 \text {-1975: Construction of wood and rock } \\
\text { groins located every block of Miami Beach }\end{array}$ & $\begin{array}{l}\text { May have temporarily built } \\
\text { up the beach }\end{array}$ & $\begin{array}{l}\text { Unattractive. Blocked } \\
\text { the natural flow of sand }\end{array}$ & --- \\
\hline $\begin{array}{l}\text { 1975-1982: nourishment of } \sim 17 \mathrm{~km} \text { of } \\
\text { beach. } \\
\text { 1986-1988 the second phase of the project. } \\
\text { Extension of the nourishment an } 4.0 \mathrm{~km} \text {. A } \\
\text { total of 14,076,765 cubic meters of sand } \\
\text { were used. }\end{array}$ & $\begin{array}{l}\text { Part of Miami Beach was } \\
\text { protected. } 80 \% \text { reduction } \\
\text { in storm damage during a } \\
100 \text {-year storm event. This } \\
\text { project is thought to be one } \\
\text { of the most durable } \\
\text { replenishment projects in } \\
\text { the US }\end{array}$ & $\begin{array}{l}\text { Costly. Harm to } \\
\text { offshore coral reef } \\
\text { habitats. Burial of } \\
\text { intertidal habitats }\end{array}$ & YES \\
\hline $\begin{array}{l}\text { 2000:In response to } 1992 \text { Hurricane Andrew } \\
\text { the State of Florida Building Commission } \\
\text { adopted the Florida Building Code (FBC) }\end{array}$ & $\begin{array}{l}\text { stricter building standards } \\
\text { for construction, } \\
\text { modification and repair }\end{array}$ & $\begin{array}{l}\text { Amendments every } \\
\text { three years }\end{array}$ & YES \\
\hline $\begin{array}{l}\text { 2014: The City of Miami Beach began to } \\
\text { implement the MDC recommendation for } \\
\text { SLR with the development of design } \\
\text { standards for city infrastructure that would } \\
\text { account for SLR during a } 30 \text { to } 50 \text { year time } \\
\text { horizon. For example, basic standards were } \\
\text { altered to increase the storm rainfall events } \\
\text { from } 15 \text { to } 19 \mathrm{~cm} \text { during a } 24 \text { hour period, } \\
\text { and tailwater elevations were increased } \\
\text { from } 20.4 \text { to } 82.3 \mathrm{~cm} \text { North American } \\
\text { Vertical Datum (NAVD). }\end{array}$ & Benefits for the future & $\begin{array}{l}\text { No requirements for } \\
\text { existing infrastructure }\end{array}$ & YES \\
\hline $\begin{array}{l}\text { 2017: Miami Beach has begun to elevate } \\
\text { streets in areas that are most vulnerable to } \\
\text { flooding. }\end{array}$ & $\begin{array}{l}\text { Elimination of street } \\
\text { flooding in low-lying areas }\end{array}$ & $\begin{array}{l}\text { Potential flooding of } \\
\text { businesses that are } \\
\text { lower than the elevated } \\
\text { streets }\end{array}$ & YES \\
\hline $\begin{array}{l}\text { 2017-2018: Overhaul of the stormwater } \\
\text { system in Miami Beach with the installation } \\
\text { of } 70 \text { one-way pumps in areas that are most } \\
\text { susceptible to flooding. }\end{array}$ & $\begin{array}{l}\text { The pumps have worked } \\
\text { during recent flooding } \\
\text { events. }\end{array}$ & $\begin{array}{l}\text { Expensive. } \\
\text { Degradation of } \\
\text { Biscayne Bay water } \\
\text { quality from street } \\
\text { runoff }\end{array}$ & YES \\
\hline \multicolumn{4}{|l|}{ Recommendations \& Future } \\
\hline $\begin{array}{l}\text { 2012: Regional Climate Action Plan with } \\
110 \text { Action Items. Reduction of greenhouse } \\
\text { gas emissions, and emergency management } \\
\text { that decision-makers at the county and } \\
\text { municipal levels can adopt to mitigate and } \\
\text { adapt to climate change. }\end{array}$ & $\begin{array}{l}\text { Although it will take many } \\
\text { years to adopt and } \\
\text { implement the } \\
\text { recommendations, these } \\
\text { are important initial } \\
\text { planning steps }\end{array}$ & Not yet implemented & YES \\
\hline $\begin{array}{l}\text { The RCAP recommended that } \\
\text { municipalities and counties develop policies } \\
\text { and standards to improve resilience to } \\
\text { coastal and other impacts from climate } \\
\text { change and sea level rise and include these } \\
\text { in their planning documents. } \\
\text { The RCAP encouraged local governments } \\
\text { to incorporate the concept of "Adaptation } \\
\text { Action Area" into their planning documents, } \\
\text { identify areas vulnerable to coastal flooding } \\
\text { and sea level rise. An additional } \\
\text { recommendation concerns the development } \\
\text { of sea level rise scenario maps and flood } \\
\text { maps that reflect the } 100 \text {-year storm event }\end{array}$ & $\begin{array}{l}\text { Building and land use } \\
\text { codes should be revised to } \\
\text { reduce losses from new } \\
\text { construction } \\
\text { or redevelopment in areas } \\
\text { vulnerable to sea level rise } \\
\text { and flooding. }\end{array}$ & Not yet implemented & YES \\
\hline
\end{tabular}




\begin{tabular}{|c|c|c|c|}
\hline $\begin{array}{l}\text { under future sea level rise scenarios to } \\
\text { incorporate into Comprehensive Planning } \\
\text { documents. }\end{array}$ & & & \\
\hline $\begin{array}{l}\text { 2013: MDC formed the Sea-Level Rise } \\
\text { Task Force charged with making } \\
\text { recommendations to the County's } \\
\text { Comprehensive Development Master Plan. } \\
\text { The principal recommendation was to } \\
\text { "accelerate the adaptation planning process } \\
\text { by seeking and formally selecting the } \\
\text { engineering and other relevant expertise } \\
\text { needed" to develop plans for flood } \\
\text { protection, salinity barriers, pumps, and } \\
\text { road/bridge designs. }\end{array}$ & $\begin{array}{l}\text { Comprehensive } \\
\text { Development Master Plan } \\
\text { includes climate change } \\
\text { adaptation measures. }\end{array}$ & $\begin{array}{l}\text { These goals are } \\
\text { important first steps, } \\
\text { but they remain to be } \\
\text { fully implemented }\end{array}$ & YES \\
\hline $\begin{array}{l}\text { 2016: the City of Miami Beach adopted new } \\
\text { standards for major renovation and new } \\
\text { construction that will provide for increased } \\
\text { protection against storm surges and sea level } \\
\text { rise. }\end{array}$ & $\begin{array}{l}\text { Protection against sea level } \\
\text { rise and storm surges. }\end{array}$ & $\begin{array}{l}\text { Not required for } \\
\text { existing structures. }\end{array}$ & YES \\
\hline $\begin{array}{l}\text { 2017: Miami-Dade County CDMP for } \\
\text { 2020-2030 contains } 12 \text { elements, several } \\
\text { which directly address climate change and } \\
\text { sea level rise. The two most relevant } \\
\text { elements are Land Use and Coastal } \\
\text { Management. The Land Use Element states } \\
\text { lofty goals of identifying hazard-prone areas } \\
\text { and areas vulnerable to SLR and tidal } \\
\text { flooding; identifying the most vulnerable } \\
\text { public infrastructure. Revising the Land Use } \\
\text { and Zoning Maps to take flooding and storm } \\
\text { surge risk into account; coordinating efforts } \\
\text { with other jurisdictions, and not subsidizing } \\
\text { programs that encourage growth on barrier } \\
\text { islands. This element also states that SLR } \\
\text { projections determined by the SEFRCCC } \\
\text { should be considered in all future County } \\
\text { decisions regarding location, design, and } \\
\text { development of public facilities and } \\
\text { infrastructure. }\end{array}$ & $\begin{array}{l}\text { Comprehensive } \\
\text { Development Master Plan } \\
\text { includes climate change } \\
\text { adaptation measures. }\end{array}$ & $\begin{array}{l}\text { These goals are } \\
\text { important first steps, } \\
\text { but they remain to be } \\
\text { fully implemented. }\end{array}$ & YES \\
\hline $\begin{array}{l}\text { 2017: the Office of Emergency } \\
\text { Management of MDC released an updated } \\
\text { of Florida Comprehensive Emergency } \\
\text { Management Plan (CEMP). This extensive } \\
\text { document specifies the responsibilities of } \\
\text { the federal, state, and local governments, as } \\
\text { well as organized stakeholders, in the face } \\
\text { of various emergency situations that may } \\
\text { occur and attempts to coordinate planning, } \\
\text { response, mitigation, and recovery from } \\
\text { identifiable hazards }\end{array}$ & $\begin{array}{l}\text { Useful to identify storm } \\
\text { surge planning zones based } \\
\text { on current sea levels. } \\
\text { Fosters inter-governmental } \\
\text { cooperation. }\end{array}$ & --- & YES \\
\hline
\end{tabular}





Fig. 1

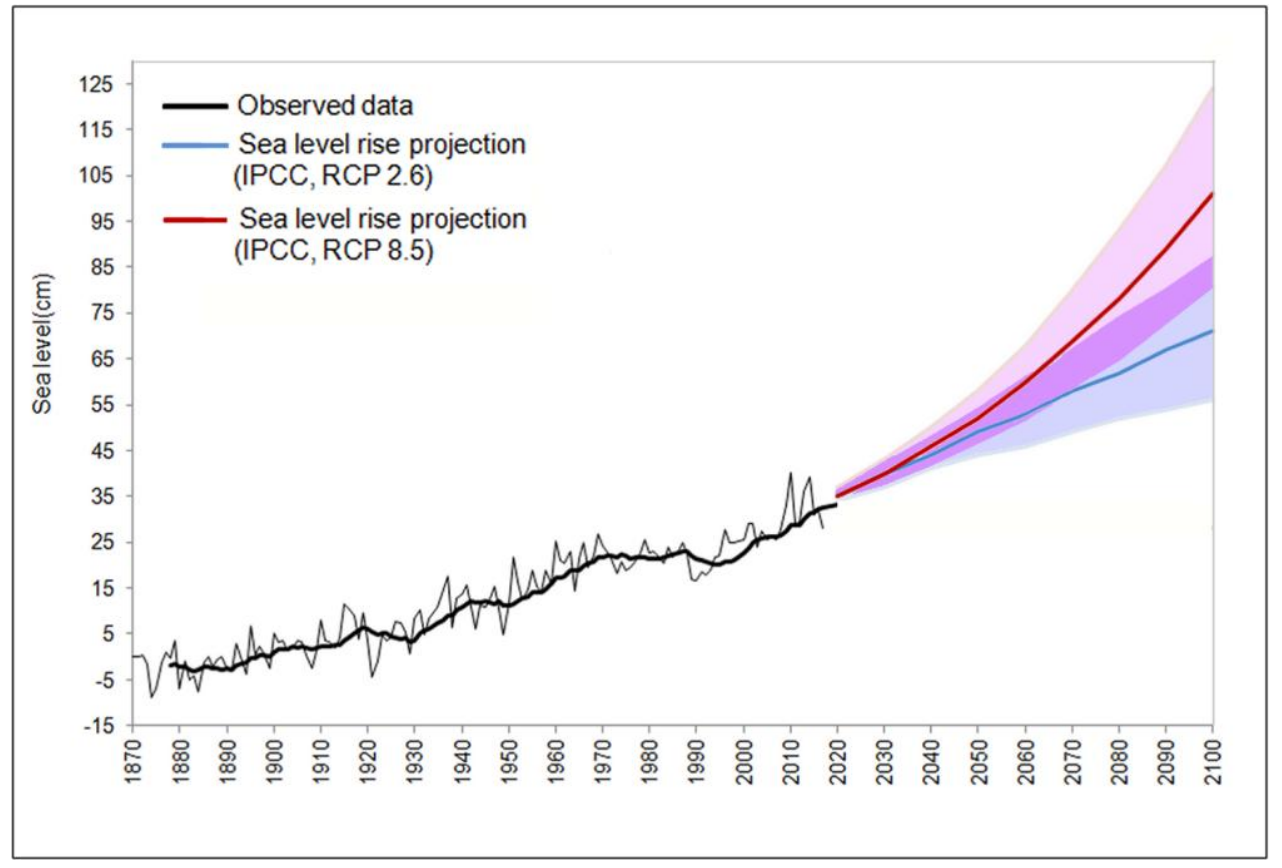

Fig. 2 




Fig. 3



Fig. 4 


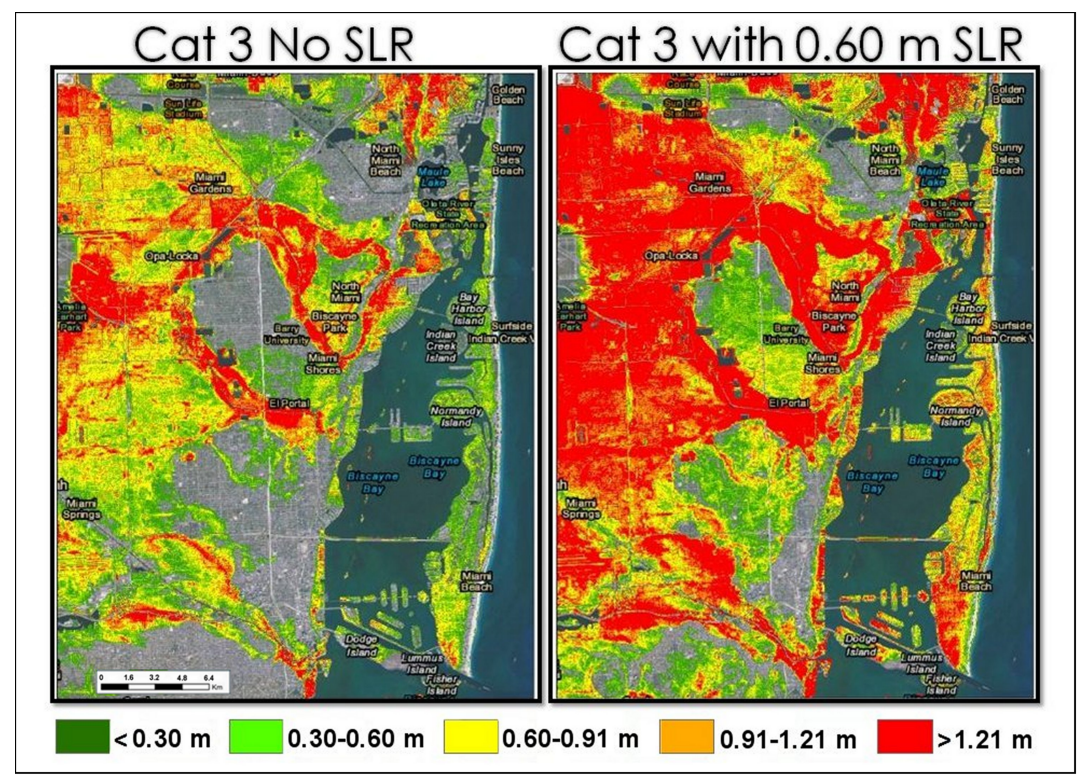

Fig. 5

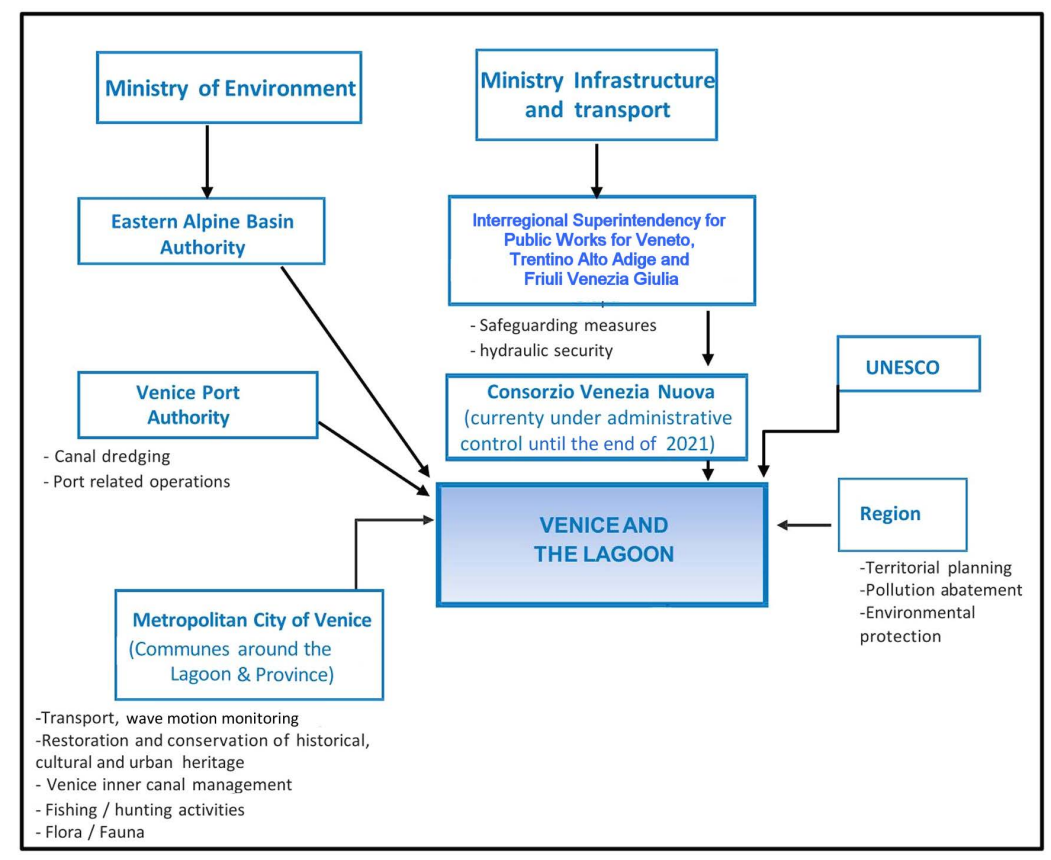

Fig. 6 


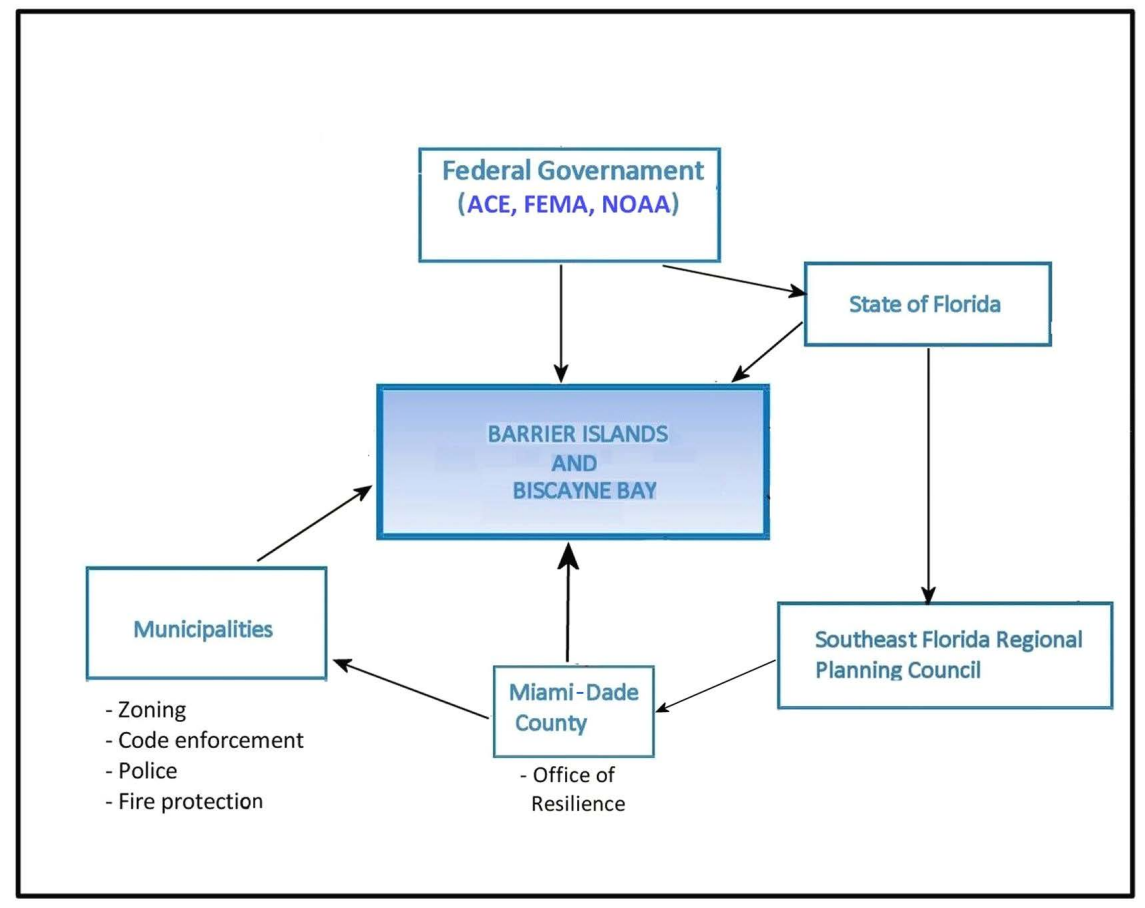

Fig. 7 



\section{Supplementary Material}

\section{List of interview and related documents (Venice)}

\section{List of Interviews}

Metropolitan City (previously Venice Province): Massimo Gattolin, Resilient Venice Venice

http://politicheambientali.cittametropolitana.ve.it/documenti/patto-dei-sindaci/venezia-citta-metropolitana-resiliente:

Veneto Region: Roberto Pelloni. Piano Paesaggistico Regionale d'Ambito "Arco Costiero Adriatico Laguna di Venezia e Delta del Po" (Regional Landscape Plan "Adriatic Coastal Arch" Venice Lagoon and Po Delta). http://bur.regione.veneto.it/BurvServices/pubblica/DettaglioDgr.aspx?id=298620

Pellestrina Municipality: Denis Carella, Plan of the beaches of Isola del Lido and Pellestrina

Osserva torio Laguna: Marco Favaro, PAES del Comune di Venezia (Sustainable Energy Action Plano f Venice Municipality: http://www.comune.venezia.it/archivio/54950).

Corila: Pierpaolo Campostrini. Piano Morfologico e ambientale della Laguna di Venezia. (Morphological and Environmental Plan of Venice lagoon ): http://www.va.minambiente.it/itIT/Oggetti/Documentazione/1446/2023?pagina=1

Associazione Ambiente Venezia: Armando Danella, https://ytali.com/2018/05/03/mose-ce-ancora-unalternativa/

Antonio Rusconi, ex-magistrato alle Acque (two intervieves: November 2016, August 2017).

\section{Documents}

UNESCO, 2011. Venice and its Lagoon: Management Plan 2012-2018. http://www.veniceandlagoon.net/web/wpcontent/uploads/2014/12/MP_volume low eng.pdf

Contratto di Costa : http://contrattodifocedeltadelpo.com/2016/03/06/erosione-e-problematiche-della-costa-veneta-ilministro-galletti-a-bibione-per-lavvio-del-contratto-di-costa-veneta/

Geodatabase gestionale delle coste venete (Coastal management geodatabase) http://sistemavenezia.regione.veneto.it/sites/default/files/documents/08_Shape/RelazioneGCV-rev-ott2015_0.pdf

Tavolo Nazionale Erosione Costiere (National Coastal Erosion Group), http://www.isprambiente.gov.it/it/news/istituito-il-tavolo-nazionale-sull2019erosione-costiera

Dune e strumenti di pianificazione: il piano dell'arenile del Lido di Venezia. (Dunes and planning tools: the Lido of Venice beach plan), 2008. (https://www.researchgate.net/publication/242162339_Dune_e_strumenti_di_pianificazione_il_piano_dell'arenile_d el_Lido_di_Venezia)

Veneto Regional Government. Dipartimento del Suolo e Foreste, Sezione Difesa del Suolo Gestione integrate della fascia costiera: studio e monitoraggio per la definizione degli interventi di difesa dei litorali dall'erosione nella regione Veneto, linee guida (Integrated management of the coastal zone: Study and monitoring for the definition of the interventions to protect the coasts from erosion in the Veneto Region, guidelines), 2016.

Autorità Portuale (Port Authority):_11-14 ottobre 2016: Green Port Conference https://www.port.venice.it/it/greenport-conference-2016.html

Metropolitan City. Piano particolareggiato dell'arenile dell'isola di Pellestrina in variante parziale al PRG ai sensi dell'Art.50, commi da 10 a 14 della L.R. 61/85 in attuazione del Piano Regionale di utilizzazione del Demanio Marittimo a finalità turistico-ricreativa (Detailed plan of the Pellestrina Island shores in partial variant to the PRG according to the Art. 50, paragraphs 10 to 14 of the L.R. 61/85 implementation of the Regional Plan for the utilization of the Maritime Property for tourism and recreational Purposes), 2010.

Metropolitan City. Piano Particolareggiato dell'Arenile dell'Isola del Lido in Variante Parziale al Piano degli Interventi-PRG per l'Isola del Lido, ai sensi dell'art.47 della L.R. 33/2002 (Detailed plan of the Lido Island shores in partial variant to the Piano of the Interventions-PRG for the Island of the Lido, in accordance with the art.47 of the L.R. 33/2002), 2018.

Provveditorato Interregionale alle Opere Pubbliche per il Veneto, Trentino Alto Adige e Friuli Venezia Giulia. Piano Morfologico della Laguna di Venezia. Morphological plan of the Venice Lagoon, 2016.

\section{List of interview and related documents (Miami)}

\section{List of Interviews}

Brian Soden, RSMAS, University of Miami 
Galen Truer, Abess Center for Ecosystem Science and Policy, University of Miami

Sandra St. Hilaire, Resilience Office, Miami-Dade County

Don Olsen, RSMAS, University of Miami

Flavia Tonioli, Sustainability Officer, City of Miami Beach

Blayne Ross, ShoreLock LLC.

Spencer Crowley, Akermann Law Firm, Miami

\section{Documents}

City of Miami Beach Planning Department. Ordinance Amendments: Freeboard \& Grade Elevations and Height. 22 March 2016.

City of Miami Beach. FREEBOARD ORDINANCE NO. 2016-4009.

AN ORDINANCE OF THE MAYOR AND CITY COMMISSION OF THE CITY OF MIAMI BEACH, FLORIDA, AMENDING SUBPART A - GENERAL ORDINANCES, OF THE CITY CODE, BY AMENDING CHAPTER 54 " FLOODS" AT SECTION 54-35, " DEFINITIONS," BY AMENDING THE DEFINITIONS FORBASE FLOOD ELEVATION, CROWN OF ROAD, AND FREEBOARD, AND BY CREATING DEFINITIONS FOR CENTERLINE OF ROADWAY, CRITICAL FACILITY, FUTURE CROWN OF ROAD, MINIMUM FREEBOARD, MAXIMUM FREEBOARD, GREEN INFRASTRUCTURE, LOW IMPACT DEVELOPMENT LID), AND SURFACE STORMWATER SHALLOW CONVEYANCE; BY AMENDING SECTION 54-45, " PERMIT PROCEDURES," TO REQUIRE A STORMWATER MANAGEMENT PLAN; BY AMENDING SECTION 54-47, GENERAL STANDARDS," TO PROHIBIT SEPTIC SEWAGE SYSTEMS, AND INCLUDE REQUIREMENTS FOR STORAGE OF HAZARDOUS MATERIALS; BY AMENDING SECTION 54-48, " SPECIFIC STANDARDS," TO CLARIFY THE MINIMUM ELEVATION OF THE LOWEST FINISHED FLOOR FOR RESIDENTIAL AND NON- RESIDENTIAL CONSTRUCTION, AND REQUIRING A MINIMUM ELEVATION FOR GARAGE ENTRANCES; BY AMENDING SECTION 54-51, " STANDARDS FOR COASTAL HIGH HAZARD AREAS ( V ZONES)," TO CLARIFY THE MINIMUM ELEVATION OF THE LOWEST FLOOR OF ALL NEW CONSTRUCTION AND SUBSTANTIAL IMPROVEMENTS; PROVIDING CODIFICATION; REPEALER; SEVERABILITY; AND AN EFFECTIVE DATE. 2016.

City of Miami Beach. RESOLUTION NO 201328142. A RESOLUTION OF THE MAYOR AND CITY COMMISSION OF THE_CITY OF MIAMI BEACH COUNTY FLORIDA ENDORSING THE_MAYORS CLIMATE ACTION PLEDGE AFFIRMING SUPPORT FOR THE SOUTHEAST FLORIDA REGIONAL CLIMATE CHANGE COMPACT AGREEING TO CONSIDER IMPLEMENTING THE REGIONAL CLIMATE ACTION PLAN IN WHOLE OR IN PART AS APPROPRIATE FOR EACH MUNICIPALITY AND URGING ALL MAYORS OF MIAMIDADE COUNTY TO SUPPORT THE MAYORS CLIMATE ACTION PLEDGE. 2013.

Florida Department of Community Affairs. Florida Building Commission. The Florida Building Code.

http://www.sbafla.com/method/portals/methodology/windstormmitigationcommittee/2009/20090917_dixonflbldgcode. pdf (Florida Building Codes)

Miami-Dade County. Beach Erosion Control Master Plan. 2010.

Miami-Dade County, Office of Emergency Management. Comprehensive Emergency Management Plan. 2017. http://www.miamidade.gov/environment/beach-renourishment.asp http://web.miamibeachfl.gov/publicworks/environmental/scroll.aspx?id=78915

Southeast Florida Regional Climate Change Compact Counties, A Region Responds to a Changing Climate: Regional Climate Action Plan, 2012.

Southeast Florida Regional Climate Change Compact Sea Level Rise Work Group, Unified Sea Level Rise Projection for Southeast Florida, 2015. 
Table 1 Chronology of events recognized as strong factors able to affect structures and processes in the morphobathymetry of Venice Lagoon from1880 to present time (modified from Sarretta et al. 2010*).

\begin{tabular}{|c|c|c|}
\hline & Event & Notes \\
\hline \multicolumn{3}{|l|}{ First period } \\
\hline $1880-1900$ & First instrument monitoring water level & Tidal gauge at Punta della Salute \\
\hline $1882-1910$ & New jetties at Lido inlet & Modification of lagoon-sea exchanges \\
\hline $1910-1934$ & New jetties at Chioggia inlet & Modification of lagoon-sea exchanges \\
\hline 1928 & $\begin{array}{l}\text { Fish farming areas separated from rest of } \\
\text { Venice Lagoon }\end{array}$ & $\begin{array}{l}\text { Reduction of lagoon surface area }(85 \\
\left.\mathrm{km}^{2}\right) / \text { reduction of water residence time }\end{array}$ \\
\hline $1917-1935$ & $\begin{array}{l}\text { Land reclamation for } 1^{\text {st }} \text { industrial zone } \\
\text { (IZ) }\end{array}$ & $\begin{array}{l}\text { Saltmarsh destruction, }\left(5 \mathrm{~km}^{2} \text {, west of city of }\right. \\
\text { Venice) }\end{array}$ \\
\hline $1931-1934$ & $\begin{array}{l}\text { Construction of trans-lagoon bridge } \\
\text { (Ponte della Libertà) }\end{array}$ & Modification of tidal current pattern \\
\hline $1950-1953$ & Land reclamation for $2^{\text {nd }}$ industrial zone & Saltmarsh destruction $\left(5 \mathrm{~km}^{2}\right.$, south of $1 \mathrm{st} \mathrm{IZ)}$ \\
\hline 1957 & $\begin{array}{l}\text { Land reclamation for housing (S. } \\
\text { Giuliano, east of Mestre) }\end{array}$ & $\begin{array}{l}\text { Saltmarsh destruction }\left(2 \mathrm{~km}^{2} \text {, north of trans- }\right. \\
\text { lagoon bridge })\end{array}$ \\
\hline $1958-1962$ & Airport construction & $\begin{array}{l}\text { Saltmarsh destruction }\left(\sim 3 \mathrm{~km}^{2}\right) \text {, excavation of } \\
\text { new artificial canal from airport to Venice }\end{array}$ \\
\hline 1962 & $\begin{array}{l}\text { Land reclamation for } 3^{\text {rd }} \text { industrial zone } \\
\text { (never completed), now called "Casse di } \\
\text { Colmata", i.e., unfinished reclamation } \\
\text { islands }\end{array}$ & $\begin{array}{l}\text { Saltmarsh destruction }\left(12 \mathrm{~km}^{2} \text {, south of } 2 \mathrm{nd}\right. \\
\mathrm{IZ})\end{array}$ \\
\hline $1966-1969$ & $\begin{array}{l}\text { Excavation of Malamocco-Marghera } \\
\text { navigation channel ("Oil Canal')) }\end{array}$ & $\begin{array}{l}30-50 \mathrm{Mm} 3 \text { of sediments disposed of in } \\
\text { landfill areas outside the lagoon/modification of } \\
\text { hydrodynamic conditions }\end{array}$ \\
\hline $1930-1970$ & Major development of industrial activities & $\begin{array}{l}\text { From } 1932 \text { to } 1972, \sim 12 \mathrm{~cm} \text { of subsidence were } \\
\text { due to water extraction for industrial use }\end{array}$ \\
\hline \multicolumn{3}{|l|}{ Second period } \\
\hline From ' 70 s on & Dredging of Porto Marghera channels & $\begin{array}{l}\text { Disposal of } 5-15 \mathrm{Mm}^{3} \text { of polluted sediments, } \\
\text { in part outside lagoon }\end{array}$ \\
\hline $\begin{array}{l}1970-1980 \\
\text { inside lagoon }\end{array}$ & $\begin{array}{l}\text { Increased discharges from industrial area } \\
\text { (nutrients, metals, POPs) }\end{array}$ & $\begin{array}{l}\text { Part of sediments becoming more and more } \\
\text { polluted, and thus not suitable for re-use }\end{array}$ \\
\hline $\begin{array}{l}80 \mathrm{~s} \\
\text { (Continued) }\end{array}$ & $\begin{array}{l}\text { Eutrophication and subsequent macro- } \\
\text { algae blooms and anoxia }\end{array}$ & $\begin{array}{l}\text { Lagoon bed covered by high quantity of } \\
\text { biomass (up to } 10-25 \mathrm{~kg} \mathrm{~m}^{-2} \text { ) }\end{array}$ \\
\hline Middle '80s & $\begin{array}{l}\text { Introduction of Manila clam for } \\
\text { aquaculture purposes }\end{array}$ & $\begin{array}{l}\text { Concession of lagoon areas }\left(\sim 14 \mathrm{~km}^{2}\right) \text { for clam } \\
\text { cultivation and harvesting (seagrass loss, } \\
\text { sediment re-suspension and alteration of } \\
\text { physical properties) }\end{array}$ \\
\hline From 1990 & Dredging for renovation of port area & $\begin{array}{l}3-5 \mathrm{Mm}^{3} \text { of sediments, partly disposed of } \\
\text { outside lagoon }\end{array}$ \\
\hline 1992 & $\begin{array}{l}\text { Construction of artificial "Tresse" island } \\
\text { to dispose of polluted industrial waste }\end{array}$ & Saltmarsh destruction $\left(\sim 2 \mathrm{~km}^{2}\right)$ \\
\hline $90 \mathrm{~s}$ & $\begin{array}{l}\text { "Invasion' of Venice Lagoon by Manila } \\
\text { clam }\end{array}$ & $\begin{array}{l}\text { Disturbance of sediments through mechanical } \\
\text { clam harvesting }\end{array}$ \\
\hline $1990-2000$ & $\begin{array}{l}\text { Construction of artificial saltmarshes }(\sim 4 \\
\left.\mathrm{km}^{2}\right)\end{array}$ & $\begin{array}{l}\text { Re-use of nonpolluted sediments dredged from } \\
\text { channels }\left(3-4 \mathrm{Mm}^{3}\right)\end{array}$ \\
\hline 2004-present & $\begin{array}{l}\text { Beginning of MoSE project. Construction } \\
\text { of storm surge barriers. }\end{array}$ & $\begin{array}{l}\text { Modification of lagoon-sea exchange and } \\
\text { sorroundings (protected areas) }\end{array}$ \\
\hline
\end{tabular}

(*) Sarretta A, Pillon S, Molinaroli E, Guerzoni S, Fontolan G (2010) Sediment budget in the Lagoon of Venice, Italy. Continental Shelf Research 30:934-949. http://doi:10.1016/j.csr.2009.07.002 
Table 2 Chronology of events referring to the transformation of the Biscayne Bay ecosystem able to affect structures and morphological processes (data from Cantillo et al. 2000\#).

\begin{tabular}{|c|c|c|}
\hline $\begin{array}{l}\text { CANALS, CUTS } \\
\text { AND THE } \\
\text { MIAMI RIVER }\end{array}$ & Event & Notes \\
\hline 1896 & $\begin{array}{l}\text { A shallow channel was dredged from Cape } \\
\text { Florida to the Miami River }\end{array}$ & $\begin{array}{l}\text { At the turn of the century, port activities in } \\
\text { the Miami area were centered in the Miami } \\
\text { River }\end{array}$ \\
\hline $1902-1908$ & $\begin{array}{l}\text { Government Cut Construction, widened and } \\
\text { deepened }\end{array}$ & $\begin{array}{l}\text { Channel providing access to the Port of } \\
\text { Miami from the ocean }\end{array}$ \\
\hline 1910-1925 & $\begin{array}{l}\text { Several channel have been dreged. } \\
7 \mathrm{~km} \text { of Miami Canal completed }\end{array}$ & $\begin{array}{l}\text { Miami Canal was } 16 \mathrm{Km} \text { long. } \\
\text { Snapper Creek Canal;Cutler Canal and the } \\
\text { Coral Gables Waterway; Collins Canal }\end{array}$ \\
\hline 1925 & Intracoastal Waterway & (Toner, 1979); (Michel, 1976) \\
\hline $1930 \mathrm{~s}$ & $\begin{array}{l}\text { River subjected to contamination from } \\
\text { commercial activities and sewage }\end{array}$ & $\begin{array}{l}\text { The sediments of the Miami River were } \\
\text { contaminated ( } \mathrm{As}, \mathrm{Cd} \mathrm{Hg}, \mathrm{Pb} \text { and } \mathrm{Ag} \text { ) }\end{array}$ \\
\hline $1940 \mathrm{~s}$ & $\begin{array}{l}\text { Salt intrusion arrested but problems remain. Salt } \\
\text { water intrusion and fresh water discharges in the } \\
\text { River and canal system were controlled through a } \\
\text { series of dams }\end{array}$ & $\begin{array}{l}\text { The inflow of salt water into the River was } \\
\text { the result of tidal action from Biscayne Bay } \\
\text { and changes in the water table resulting } \\
\text { from the construction of the drainage canal } \\
\text { system }\end{array}$ \\
\hline $\begin{array}{l}\text { BULKHEADING } \\
\text { AND RELATED } \\
\text { ACTIVITIES }\end{array}$ & & \\
\hline $1913-1925$ & $\begin{array}{l}\text { Mangroves cut down in southern Miami Beach } \\
\text { and in Miami Beach and swamps filled } \\
\text { Bayview section of Miami Shores filled. } \\
\text { Area east of Biscayne Blvd. filled to create } \\
\text { Bayfront Park }\end{array}$ & $\begin{array}{l}\text { The first bridge to Miami Beach was built in } \\
\text { and Carl Fisher began development of } \\
\text { Miami Beach as a tourist resort. } \\
\text { The western edge of the Bay was dredged to } \\
\text { provide fill for Bayfront Park }\end{array}$ \\
\hline $1950 \mathrm{~s}$ & $\begin{array}{l}\text { Southern one-fourth of Key Biscayne bulk- } \\
\text { headed and filled }\end{array}$ & $\begin{array}{l}\text { Over } 80 \text { ha of wetlands were destroyed in } \\
\text { southern Key Biscayne through dredge and } \\
\text { fill operations associated with failed } \\
\text { developments }\end{array}$ \\
\hline $1970 \mathrm{~s}$ & Dredge and fill activities at Fair Isle & $\begin{array}{l}\text { Possible damage may have occurred in the } \\
\text { area due to dredge and fill }\end{array}$ \\
\hline \multicolumn{3}{|l|}{ ISLANDS } \\
\hline $1902-1944$ & $\begin{array}{l}\text { Creation of several islands with dredged material } \\
\text { from rivers }\end{array}$ & $\begin{array}{l}\text { The islands: Fisher Island; Belle Isle; } \\
\text { Venetian Islands and Pelican Island; Watson } \\
\text { Island }\end{array}$ \\
\hline \multicolumn{3}{|l|}{$\begin{array}{l}\text { PORT OF } \\
\text { MIAMI }\end{array}$} \\
\hline 1896 & Port of Miami opens & $\begin{array}{l}\text { The shallow channel between Cape Florida } \\
\text { and the river provided access to larger } \\
\text { vessels }\end{array}$ \\
\hline $1915-1920 \mathrm{~s}$ & $\begin{array}{l}\text { Government Cut was constructed through Miami } \\
\text { Beach, providing port access to larger vessels. } \\
\text { The MacArthur Causeway, linking Miami and } \\
\text { Miami Beach, was built }\end{array}$ & $\begin{array}{l}\text { Port is primary hub for all shipping to South } \\
\text { Florida }\end{array}$ \\
\hline $1956-1964$ & $\begin{array}{l}\text { The Port selected Dodge Island for future } \\
\text { expansion. Work began on the Dodge Island } \\
\text { Seaport }\end{array}$ & Dodge Island Seaport opens \\
\hline $1976-1980$ & $\begin{array}{l}\text { First port in history to record more than one } \\
\text { million passengers in a year }\end{array}$ & $\begin{array}{l}\text { Oceanographic research vessels of NOAA } \\
\text { and the University of Miami Rosenstiel } \\
\text { Institute of Marine Sciences used the Port of } \\
\text { Miami as home }\end{array}$ \\
\hline 1981 & Port expanded to Lummus Island & $\begin{array}{l}\text { Passenger and cargo records continued to be } \\
\text { set }\end{array}$ \\
\hline 1991 & $\begin{array}{l}\text { One of the last modifications to the Port was the } \\
\text { infilling of small ship basins on the perimeter of } \\
\text { Dodge-Lummus Islands }\end{array}$ & $\begin{array}{l}\text { A record } 3.9 \text { million tons of cargo are } \\
\text { handled in one year }\end{array}$ \\
\hline
\end{tabular}




\begin{tabular}{|l|l|l|}
\hline 1999 & $\begin{array}{l}\text { Royal Caribbean's Voyager of the Seas, the } \\
\text { largest cruise ship ever constructed, is based at } \\
\text { the Port }\end{array}$ & $\begin{array}{l}\text { Port of Miami is now the first cruise ship } \\
\text { harbour in the world }\end{array}$ \\
\hline $\begin{array}{l}\text { ARTIFICIAL } \\
\text { REEFS }\end{array}$ & $\begin{array}{l}\text { Heaviest reef construction. Seven artificial reefs } \\
\text { located within Biscayne Bay proper }\end{array}$ & $\begin{array}{l}\text { North Bayshore Park Reef; San Souci Reef; } \\
\text { Pelican Harbor Reef; Julia Tuttle Artificial } \\
\text { Reef; Brickell Area Reef; Rickenbacker } \\
\text { Causeway Reef; Mercy Hospital Reef }\end{array}$ \\
\hline $1987-1991$
\end{tabular}

(\#) Cantillo AY, Hale K, Collins E, Pikula L, Caballero R (2000) Environmental History and Annotated Bibliography. NOAA Technical Memorandum NOS NCCOS CCMA 145. 


\section{Political-Administrative Environments}

\section{The new institutional setting in Venice}

"Provveditorato Interregionale alle Opere Pubbliche per il Veneto, Trentino Alto Adige e Friuli Venezia Giulia", a branch of the national Ministry of Infrastructure and Transport, is responsible for pollution abatement and maintenance in the lagoon, as well as flood defenses. It has replaced the Venice Water Authority (VWA) which was eliminated in June 2014, and its projects are largely implemented by its concessionary, the powerful Consorzio Venezia Nuova (CVN), a group of Italy's leading industrial companies and local firms, that researches, develops, and executes measures to protect Venice from flooding. The Consorzio is currently under controlled administration due to charges of managerial corruption. The Consorzio's current mandate comes to an end in 2020-21 when MoSE should be completed. No plan exists for a replacement entity.

Eastern Alpine Basin Authority. The Italian territory has been subdivided into seven Districts, and the watersheds of the Northeast have been united in the Eastern Alps District, whose boundary substantially coincides with the past territorial competences of the VWA. In 2016 the Basin Authority approved an updated Water Management Plan and the Flood Risk Management Plan. These Plans, in line with the Regional Water Protection Plans, refer to all the water bodies (surface, underground, transitional, coastal) of the Hydrographic District, and a relevant part includes the "Hydrographic Subunit of the Watershed, Venice Lagoon and Adjacent Sea".

The Veneto Regional Government is responsible for pollution abatement in the lagoon's drainage basin, tourism and transport on the mainland, landscape, and some aspects of navigation. In 2016 it released a document that identified areas at greatest risk from flooding considering different climate change scenarios (Veneto Regional Government and the University of Padova, 2016). The Regional Government's plan highlights the MoSE Project as adaptative interventions at the three lagoon inlets.

The recently created Metropolitan City of Venice will take over some of the responsibilities of the communes around the lagoon and the Province ${ }^{1}$ (previously responsible for some environmental aspects on the mainland and fisheries in the lagoon). This new institution should assert authority over the Lagoon and MoSE. The Metropolitan City could provide an opportunity for more integrated decisionmaking. However, the institutional creation of the Metropolitan City is proceeding slowly.

The Venice Port Authority, a national entity, is responsible for shipping channels across the lagoon, the Giudecca Canal through Venice, and the ports in Venice and around the lagoon. The Port Authority would like to be involved in the MoSE management because of its direct impacts on navigation.

In 1987, Venice was declared a UNESCO World Heritage Site, and consequently, Italy agreed to produce a management plan and define a "buffer zone" around Venice. By November $2012^{2}$, the plan for Venice was finally approved by the City Council. Development of the 157-page plan required more than 20 years, based on consultation with 250 public bodies that suggested 136 proposals. The document was judged to be very poor and ignored many significant issues, such as big ships, unsustainable tourism, and the decline of residents. The most significant gap in the management plan was its failure to consider SLR. Of course, the plan mentions flooding and MoSE, due to be completed at that time by 2018, but SLR is only superficially mentioned. In 2015, UNESCO warned that Venice might be included in the list of UNESCO World Heritage Sites In Danger if Italy had not banned large cruise ships from the city's lagoon by $2017^{3}$.

\section{Institutional setting in Miami}

\section{The US Army Corps of Engineers (USACE) and the Federal Emergency Management Agency (FEMA).}

Section 404 of the Clean Water Act also grants the USACE permitting autority over activities that discharge dredge or fill materials to waters of the United States. Mandated by this legislation, the USACE carries out planning and funding of regional beach renourishment projects. As part of its National Flood Insurance Program (NFIP), FEMA is charged with flood plain mapping and administering the NFIP that provides subsidized flood insurance to property owners whose communities comply with FEMA flood plain standards. The current flood plain maps prepared by the FEMA became effective in September 2009. MDC adopted the maps in July 2009 in satisfaction of the requirement for the county to participate in the National Flood Insurance Program. Structures located in flood plain zones A, AH, AE, and $\mathrm{VE}$ are eligible for subsidized flood insurance. Zones AH (flood depth from 0.3 to $0.9 \mathrm{~m}$ ) and AE (flood depth greater

\footnotetext{
${ }^{1}$ The Province in 2008 prepared a Flood Plan ("Piano Mareggiate") with a management geodatabase of the Venetian coasts containing all geomorphological data.

${ }^{2}$ http://www.veniceandlagoon.net/web/wp-content/uploads/2014/12/MP_volume_low_eng.pdf

${ }^{3}$ In 2018 the large vessels, with a maximum limit of 90,000 tons, still entered the lagoon.
} 
than $0.9 \mathrm{~m}$ ) have a moderate to high flood risk. Flood risk is high in Zone A ( 1 in 4 chance of flooding during 30 years) and Zone VE (1 in 4 chance of flooding during 30 years with additional hazards due to storm waves). However, the flood plain maps are based on historical data, are not proactive and do not currently consider SLR. A lively current issue is whether the NFIP should increase its rates to better reflect the risks.

\section{The Natural Resources Defense Council (NRDC)}

The NRDC Report stressed the importance that the Governor has in planning for climate change- "without a top-down directive from the executive level, there is unlikely to be sufficient action by all necessary government agencies within a state on climate change issues." Recent responses to climate change impacts from the Governor of the State of Florida have not been energetic. The current Governor remains skeptical about climate change claiming has established an unwritten policy that State of Florida agencies not use the phrases "climate change" and "global warming" in their documents. Reports of this policy come from Florida's Department of Environmental Protection, the Department of Transportation, the Department of Health, and the South Florida Water Management District (Korten, 2015).

The Southeast Florida Regional Planning Council (SEFRPC)

The SEFRPC adopted the Southeast Florida Regional Climate Action Plan in 2009 that laid out numerous recommendations for counties in areas of climate change adaptation and mitigation.

\section{Miami-Ddade County (MDC) and Municipalities}

MDC has developed the County Comprehensive Development Master Plan (CDMP) and an MDC, Florida Comprehensive Emergency Management Plan prepared in 2017. The CDMP lays out policies and objectives for development, land use, and natural resource use for the next 10-20 year period and then describes the means that the County will adopt to meet the objectives and deliver its services. The Board of County Commissioners has adopted Land Use Maps 2020-2030. 


\section{MoSE Project (Experimental Electromechanical Module)}

The centerpiece of the Special Law was MoSE (an acronym for Modulo Sperimentale Elettromeccanico or Experimental Electromechanical Module), begun in 2003 and expected to be completed no sooner than 2020-2022. The mobile tidal barrier project will prevent flooding through the installation of 78 mobile gates, laid at the bottom of the seabed at the three inlets Lido, Malamocco, and Chioggia - separating the Venice Lagoon from the Adriatic Sea. The manufacturers of the barriers claim that the system is designed to withstand a hypothetical average rise in sea level of $0.6 \mathrm{~m}$ and a tidal fluctuation of $3.0 \mathrm{~m}$. The mobile gates are $28 \mathrm{~m}$ long, $20 \mathrm{~m}$ wide, will weigh 300 tons, and are placed at the bottom of inlet channels supported by $38 \mathrm{~m}$ long steel and concrete pilings driven into the lagoon bed and measuring $0.5 \mathrm{~m}$ in diameter and $20 \mathrm{~m}$ in length. Compressed air is pumped into the metal-box structure when tidal events exceeding $110 \mathrm{~cm}$ are projected, protecting the city from extreme flooding. The air will raise the barriers to the water surface blocking the tidal flow and preventing water flow into the lagoon. Floodgates are hollowed at the bottom, to allow compressed air to be blown in. When there is no risk of flooding, the mobile gates will be filled with water and lowered into the seabed. Floodgates at each inlet will function independently depending on the force of the tide expected. Since 2003 the majority of funding has been dedicated to completion of the MoSE project. In the period 1992-2004 the average amount of annual funding of the Special Law dedicated to Venice was $€ 143$ million, reduced to $\sim € 20$ million in the period 2005-2014. Measures that previously had been implemented, such as wetland creation and beach nourishment, were consequently halted for lack of funding.

Strong debate has surrounded MoSE since its conception regarding its effectiveness and high cost (Ammerman and McClennen, 2000; Kaluarachchi, 2014). In their analyses of changes in the dynamics of the Venice Lagoon due to the construction of the MoSE, many authors suggest that the mobile barriers will produce changes in the structure of the lagoon inlets, with consequences for the dynamics of the lagoon ecosystem as a whole. In particular, the most intense currents may create risks for habitat conservation in the northern lagoon, while the micro-circulation between the breakwater and the coast may trap pollutants or suspended sediments in the southern lagoon area

Vergano et al. (2010) provided an estimate of the direct costs of the interruption of ship traffic due to the operation of the MoSE, resulting from longer waiting times for ships crossing the Venice Lagoon. Data of ship traffic in the period 2000-2002 indicated an additional annual cost of $€ 1.3$ million, but with updated traffic data, impacts would be around $€ 10$ million/year. Umgiesser and Maticchio (2006) showed that the interference with the ship traffic was acceptable under actual conditions but would become prohibitive with a sea-level rise of $50 \mathrm{~cm}$, when nearly two-thirds of the ship passages would be blocked or delayed. This shows the need to consider the changing impact of management schemes over the long-term.The same authors calculated that with SLR, the gates will be closed ever more frequently, thus reducing the survivability of marshes. Furthermore, the increasing number and frequency of closure events elevate environmental degradation, particularly water quality. Panza et al. (2014) have suggested that a potential seismogenic source located inland near Venice might generate a tsunami wave that could affect the MoSE gates if they are standing up (closed) during the tsunami event.

With respect to MoSE, after judicial magistrates discovered evidence of corruption, all CVN interventions have been suspended except for construction of the sea gates. The final delivery date for MoSE has been delayed and is now scheduled tentatively for 2020-2022, instead of the original completion date of 2012. Additionally, construction has been flawed with use of substandard materials, and now there are numerous protests and further delays. Some individuals question the utility of MoSE, but most people believe that the project should not be abandoned because $€ 4.5$ billion have already been invested. 